\title{
Effects Of Benzene on Human Hematopoiesis
}

\author{
Jorunn Kirkeleit ${ }^{1}$, Trond Riise ${ }^{1}$, Bjørn Tore Gjertsen ${ }^{2}$, Bente E. Moen ${ }^{1}$, Magne Bråtveit ${ }^{1}$, Øystein \\ Bruserud $^{2, *}$
}

${ }^{1}$ Section for Occupational Medicine, Department of Public Health and Primary Health Care, University of Bergen, $N$ 5018, Bergen, Norway; ${ }^{2}$ Hematology Section, Institute of Medicine, University of Bergen, N-5021 Bergen, Norway

\begin{abstract}
Benzene, an aromatic hydrocarbon that is a natural component of crude oil and natural gas, is toxic to the blood and blood-forming organs. Epidemiological studies have established an association between benzene exposure and acute myeloid leukemia, and increasing evidence also indicates a possible association between benzene and multiple myeloma. A specific benzene-associated myelodysplastic syndrome has also been suggested. Chronic hematotoxic effects of benzene exposure, including reduced lymphocyte, neutrophil and platelet counts in peripheral blood, have been detected at occupational exposure below a level that had previously been considered not to cause any health effects. Whether these abnormalities represent bone marrow damage and/or initial events in the development of a true neoplastic disease is not known. Together with a reported nonlinear relationship between benzene exposure and the level of various metabolites, favoring production of biologically reactive quinones at exposure below 1 part per million, these observations suggest that benzene even at low exposure levels may contribute to the risk of acute myeloid leukemia or myelodysplastic syndrome, especially among genetically susceptible individuals.
\end{abstract}

\section{INTRODUCTION}

This review focuses on aspects relevant when individuals with cancer ask their physician about factors in the working environment that might be related to their blood disease and for hematologists seeking updated knowledge on benzeneinduced malignancies of the blood and blood-forming organs. Leukemogenesis is a multistep process that is believed to include a combination of mutated signal transduction and perturbed transcription factors $[1,2]$. The multifactorial origin of most types of cancer, including malignancies of the blood and blood-forming organs, creates difficulty in determining the contribution of single agents. The World Health Organization (WHO) has estimated that benzene, ionizing radiation and ethylene oxide were responsible for 7000 deaths from leukemia in $2000[3,4]$. The estimated fraction attributable to these risk factors was $2 \%$ in the WHO study compared with a range of $0.8-2.8 \%$ for the United States [5] and $18 \%$ for men in Finland [6]. Although the risk associated with occupational exposure is generally several orders of magnitude less than for active smoking, dietary factors and alcohol consumption in the general population, it is high in certain groups of workers.

Benzene, an aromatic hydrocarbon that is a natural component of crude oil and petroleum products, is toxic to the blood and blood-forming organs. The cells of the hematopoietic system are the most sensitive target organs. Repeated occupational benzene exposure over long periods of time may affect several hematopoietic parameters [7-11] and eventually induce malignancies of the blood and bloodforming organs. Benzene exposure has been causally associated with increased risk of acute myeloid leukemia (AML)

*Address correspondence to this author at the Hematology Section, Institute of Medicine, University of Bergen, N-5021 Bergen, Norway;

Tel: +4755972997; Fax: +4755972950;

E-mail: oystein.bruserud@helse-bergen.no
$[12,13]$, and the associations with multiple myeloma [14,15] and non-Hodgkin's lymphoma [16,17] have been thoroughly debated. No clear evidence indicates any threshold level below which benzene does not cause hematotoxic effects in humans [18], and recent studies indicate that exposure to benzene at levels previously considered not to cause any health effects induce hematotoxicity and an increased risk of malignancies of the blood and blood-forming organs $[11,19,20]$.

\section{BENZENE EXPOSURE}

\subsection{Occupational Exposure Limits for Benzene}

Occupational exposure limits (OEL) are set to protect workers from excessive exposure to toxic chemicals in the workplace. An OEL defines the maximum average concentration of a chemical in the breathing zone acceptable for a normal 8-hour working day for 5 days a week. The OEL is often accompanied by a short-term exposure limit, which is the maximum average concentration to which workers should be exposed for a short period of time (usually 15 minutes). As the hematotoxic and leukemogenic effects have been identified at ever-lower levels, the OEL for benzene has been extensively revised and reduced from 100 parts per million (ppm) in 1946 to values ranging from 0.1 to $1 \mathrm{ppm}$ in 2008 [21]. The American Conference of Governmental Industrial Hygienists set a Treshold Limit Value of $0.5 \mathrm{ppm}$ in 1997, and the European Union has established a legal binding limit value of 1 ppm [22].

\subsection{Sources of Benzene Exposure}

\subsubsection{Occupational Exposure to Benzene}

For most job categories the reported full-shift benzene exposure in workers' breathing zone are normally low compared with present OEL. This applies to producing crude oil and natural gas [23-27], refining petroleum products [23,28- 
$30]$, distributing petrol and other petroleum products $[23,30$ 32] and working in car repair shops and petrol stations $[33,34]$.

However, although the mean exposure for long-term sampling during ordinary activity in producing crude oil and natural gas are well below $1 \mathrm{ppm}$ benzene most of the time, exposure levels up to $18 \mathrm{ppm}\left(57.6 \mathrm{mg} / \mathrm{m}^{3}\right)$ have been reported [27]. Similarly, exposure ranges from below 0.01 to $4.6 \mathrm{ppm}$ in the production of benzene and when refining other petroleum products $[28,29,35]$ and between $<0.002$ and $32.5 \mathrm{ppm}$ for the distribution of various petroleum products [31,32]. Some specific tasks typically lasting for less than 1 hour, such as tank cleaning and loading of petrol, may cause high short-term exposure [24,27,29,30,36-40].

Workers employed in car repair shops, car recycling, petrol stations and transport are potentially exposed to benzene through their contact with petrol. Reported full-shift exposure ranges between $<0.01$ and 28.02 ppm [33,34,41,42]. However, the exposure to these groups of workers is probably declining since the benzene content in petrol has been reduced through the implementation of new regulations and recommendations, at least in Europe, United States and Canada [43]. van Wijngaarden \& Stewart [44] reviewed the exposure levels in other industries such as chemical manufacture, rubber tire manufacture, steel work, laboratories, waste collection and disposal and firefighting.

\subsubsection{Non-Occupationally Related Sources of Benzene}

The major sources of benzene exposure for the general population are tobacco smoking and benzene emitted into ambient air during refueling of petrol and the combustion of petrol and other organic materials [45-47].

Smoking. Cigarette smoke is a known source of benzene and its metabolite hydroquinone [48]. Kim et al. predicted that smoking 20 cigarettes per day would be equivalent to an occupational exposure of $26 \mu \mathrm{g} / \mathrm{m}^{3}$ (approximately 0.008 ppm) [49], resulting in 52\% more hydroquinone and $20 \%$ more catechol in smoking individuals than observed in nonsmoking control subjects [50]. The estimated benzene exposure was in accordance with previous predictions for an urban smoker consuming 20 cigarettes per day [46]. In contrast, in an experimental study smokers not occupationally exposed to benzene reached a morning concentration of benzene in blood of up to $13 \mathrm{nmol} / \mathrm{l}$ after smoking four or five cigarettes [51], which is estimated to be equivalent to benzene exposure in the breathing zone of as much as $0.3 \mathrm{ppm}$ averaged over an 8-hour shift [52].

Ambient air. For the general population, the European Union has established a limit value of benzene in ambient air of $5 \mu \mathrm{g} / \mathrm{m}^{3}$ (approximately $0.0016 \mathrm{ppm}$ ) averaged over a calendar year [53]. In the United Kingdom, annual mean concentrations at urban sites range from 2.2 to $8.0 \mu \mathrm{g} / \mathrm{m}^{3}$, and data from rural sites showed a mean annual concentration of $1.3 \mu \mathrm{g} / \mathrm{m}^{3}$ [46]. The maximum hourly concentrations measured in urban and rural sites were 139 and $15.4 \mu \mathrm{g} / \mathrm{m}^{3}$, respectively. Similar results have been reported elsewhere $[45,47,54]$. Hence, the exposure level posed on the general population through refueling and combustion of petrol, passive tobacco smoking, and point sources such as petrochemical plants or oil refineries is considerable lower than the level experienced by the benzene-exposed worker.

\section{TOXICOKINETICS OF BENZENE}

\subsection{Absorption}

Inhalation is the most important route of absorption during occupational exposure to benzene. Humans absorb 30$52 \%$ of inhaled benzene, depending on the benzene concentration, length of exposure and pulmonary ventilation $[51,55,56]$. Benzene penetrates skin [57-59]. However, dermal absorption of benzene is not extensive, as it evaporates quickly due to high vapor pressure. Hence, under normal working conditions, dermal absorption of benzene is probably of minor importance [59-62].

\subsection{Metabolism}

The liver is the major site of metabolism of benzene [63] Benzene is detoxified in two phases. During phase I, benzene is oxidized by cytochrome P450 2E1, forming benzene oxide, an electrophilic reactive intermediate. Subsequently, benzene oxide is metabolized by three pathways [63]:

1) rearrangement non-enzymatically to form phenol;

2) hydration by epoxide hydrolase to 1,2-benzene dihydrodiol, which in turn can be oxidized by dihydrodiol dehydrogenase to form catechol; and

3) glutathione conjugation with glutathione $S$-transferase to form a premercapturic acid, which is converted to phenylmercapturic acid.

Phenol can undergo subsequent hydroxylation to hydroquinone, with the consecutive production of $p$-benzoquinone and 1,2,4-trihydroxybenzene. Alternatively, phenol can be hydroxylated to catechol, which is converted to $O$ benzoquinone. The benzene ring can also be opened either at the benzene oxide or oxepin stage, forming muconaldehyde. All these metabolites can then undergo a phase II metabolism, leading to excretion of glucuronide and sulfate conjugates, mercapturic acid ring-opened metabolites and DNA adducts in urine [63].

\subsubsection{Production of Toxic Metabolites in the Target Organ}

Benzene itself is not regarded as a toxic substance. Benzene toxicity is believed to involve biological interactions of multiple reactive benzene intermediates with multiple cellular targets within the bone marrow. Especially hydroquinone, $p$-benzoquinone, catechol and muconaldehyde, alone or in combination, are reported to be the most potent metabolites in producing hematotoxicity $[63,64]$.

Beside the enzyme CYP 2E1 [65], the bone marrow contains several peroxidases; the most prevalent is myeloperoxidase [66-68]. Phenol, catechol and hydroquinone are transported to the bone marrow, where myeloperoxidase is responsible for converting these metabolites to several biologically reactive quinones [68].

\subsubsection{Nonlinear Benzene Metabolism}

The production of the major benzene metabolites [49,50], as well as albumin adducts of benzene oxide and benzoquinones $[69,70]$, exhibit a nonlinear dose-response relationship attributable to saturated metabolism of benzene. For the $S$ phenylmercapturic acid there was an increasing production along with increasing benzene exposure. However, for all major metabolites competing for the cytochrome P450 2E1 
system, such as phenol, catechol, hydroquinone and muconic acid, there was in fact a decreasing trend after a transition level around $0.03 \mathrm{ppm}[49,50]$. Above this level the production of catechol and phenol dropped by 4.4 and 16-fold already when reaching exposure of $0.27 \mathrm{ppm}$, while the reduction for hydroquinone and muconic acid was only marginal. Hence, at low doses (below $1 \mathrm{ppm}$ ) the metabolism favored the production of hydroquinone and muconic acid. Hydroquinone is the precursor of the toxic 1,4-benzoquinone, whereas muconic acid is derived from the extremely reactive and toxic muconaldehydes. From these results, it was concluded that workers exposed to benzene below $0.1 \mathrm{ppm}$ metabolize benzene about nine times more efficiently and therefore more adversely than do heavily exposed workers.

\section{BENZENE TOXICITY IN HUMANS}

\subsection{Hematotoxicity Caused by Chronic Benzene Expo- sure - Bone Marrow Damage or Leukemogenesis?}

Several previous studies $[7,8,10,11,71,72]$ have described abnormalities in myeloid and lymphoid cells among workers with long-term exposure to benzene. These abnormalities have been observed even after low benzene exposure $(<1$ ppm) and include decreased circulating white blood cells, $\mathrm{CD}^{+}{ }^{\mathrm{T}}$ cells, $\mathrm{CD}^{+} / \mathrm{CD}^{+}$ratio and $\mathrm{B}$ cells, neutrophils and platelets [11]. Tests for linear trends using the benzene concentration in air as a continuous variable were significant for platelets and various leukocyte subsets except monocytes and $\mathrm{CD}^{+} \mathrm{T}$ cells. Diminished thymus function did not appear to mediate the lymphotoxicity of benzene [73]. Benzene affected progenitor cell colony formation significantly more strongly than the number of mature blood cells. The genotype of benzene detoxifying and activating enzymes influenced leukocyte toxicity - in particular myeloperoxidase and $\mathrm{NAD}(\mathrm{P}) \mathrm{H}$ :quinone oxireductase, showing a strong genedosage effect. Taken together, these results suggest that long-term exposure to benzene, even below $1 \mathrm{ppm}$, can induce hematotoxicity. However, whether these reduced levels in circulating blood cells simply represent bone marrow damage or the initial steps of a neoplastic bone marrow disease cannot be determined.

Table 1 presents studies assessing outcomes on the blood and blood-forming organs in benzene-exposed workers. Since the studies have reported effects on the blood and blood-forming organs according to different metrics of exposure, only the directions of the altered level in the respective studies are given as arrows. However, two of the studies assessed the reduction in several exposure groups. Lan et al. [11] reported that the reductions in the various exposure groups compared with the controls were $14.5-26.4 \%$ for white blood cells, $8.0-15.5 \%$ for total lymphocytes, $18.2-$ $32.1 \%$ for granulocytes and $7.0-25.2 \%$ for platelets. The corresponding ranges reported from $\mathrm{Qu}$ et al. [10] were $13.0-15.6 \%$ for red blood cells, $4.3-29.1 \%$ for white blood cells and $15.7-38.1 \%$ for neutrophils. For both these studies a significant dose-response relation were found. Importantly, several studies [74-76] also reported no decrease in blood cell counts among benzene-exposed workers or that some of the hematological parameters previously reported to be sensitive to benzene exposure, such as total number of white blood cells, neutrophils, eosinophils and monocytes, were in fact significantly increased in the exposed group compared with controls [77]. The differences in the findings of these studies could be related to the reported lower mean exposure and the use of routinely collected health surveillance data in the negative studies. Further, more of the positive studies have been done on Asians, shown to have a higher risk of benzene toxicity than other ethnic groups due to genetic polymorphism in some enzymes involved in metabolizing benzene [78,79]. Nevertheless, overall these studies show that benzene induces a hematotoxic effect in both myeloid and lymphoid cell lines.

Studies have also reported that benzene exposure affects the proteins of the immune system. These effects include reduced serum immunoglobulins [72,80-82], an anti-benzene antibody response [83] and reduced complement levels [84].

\subsubsection{Benzene-Associated Hematotoxicity and Growth Factor Signaling}

Benzene-exposed workers had reduced expression of various cytokines, including the CXC-chemokines CXCL4 (platelet factor 4) and connective tissue-activating peptide (CTAP-III), compared with unexposed workers [85]. These chemokines are mainly released by platelets, but the levels showed no correlation with peripheral blood platelet counts. Thus it was concluded that, the altered levels of these mediators probably reflect a qualitative difference between thrombocytes derived from benzene-exposed and -unexposed individuals. Twenty-nine genes, including the two chemokines CXCL4 (downregulated) and chemokine (C-X-C motif) ligand 16 (upregulated), were likely to be differentially expressed in workers heavily exposed to benzene (mean exposure $=44 \mathrm{ppm}$ ) compared with unexposed workers [86]. Thus, alteration in the cytokine network, and especially the chemokine system, seems to be important in benzene toxicity.

\subsection{Benzene-Associated Aplastic Anemia}

Chronic exposure to high benzene concentrations has long been associated with aplastic anemia [87]. Most of these cases have been diagnosed based on pancytopenia in peripheral blood, and direct examination of the bone marrow is missing for most cases [for references see 88]. Given the recent observation of hypoplastic myelodysplastic syndrome in benzene-exposed individuals (see below) [88], the reported association between benzene exposure and aplastic anemia might at least partly represent an association between benzene exposure and myelodysplasia.

\subsection{Benzene-Associated Myelodysplastic Syndrome}

Several studies [88-90] have described an association between benzene exposure and myelodysplastic syndrome, with Irons et al. [88] reporting a unique form of benzeneassociated myelodysplasia. Irons et al. included a relatively low number of patients, but they underwent detailed examination. Patients were referred to hospitals based on initial clinical presentation and/or a medical history of occupationally related benzene intoxication. Their benzene exposure was independently verified, and estimated full-shift exposure averaged between 50 and 300 ppm, which is very high compared with the OEL of 1 ppm benzene or less in most western countries [21]. The patients had been exposed for varying periods of time ranging from 6 to 22 years and were removed from exposure on average 2.7 years before evalua- 
Table 1. Selected Studies on Outcomes on the Blood and Blood-Forming Organs Among Benzene-Exposed Workers

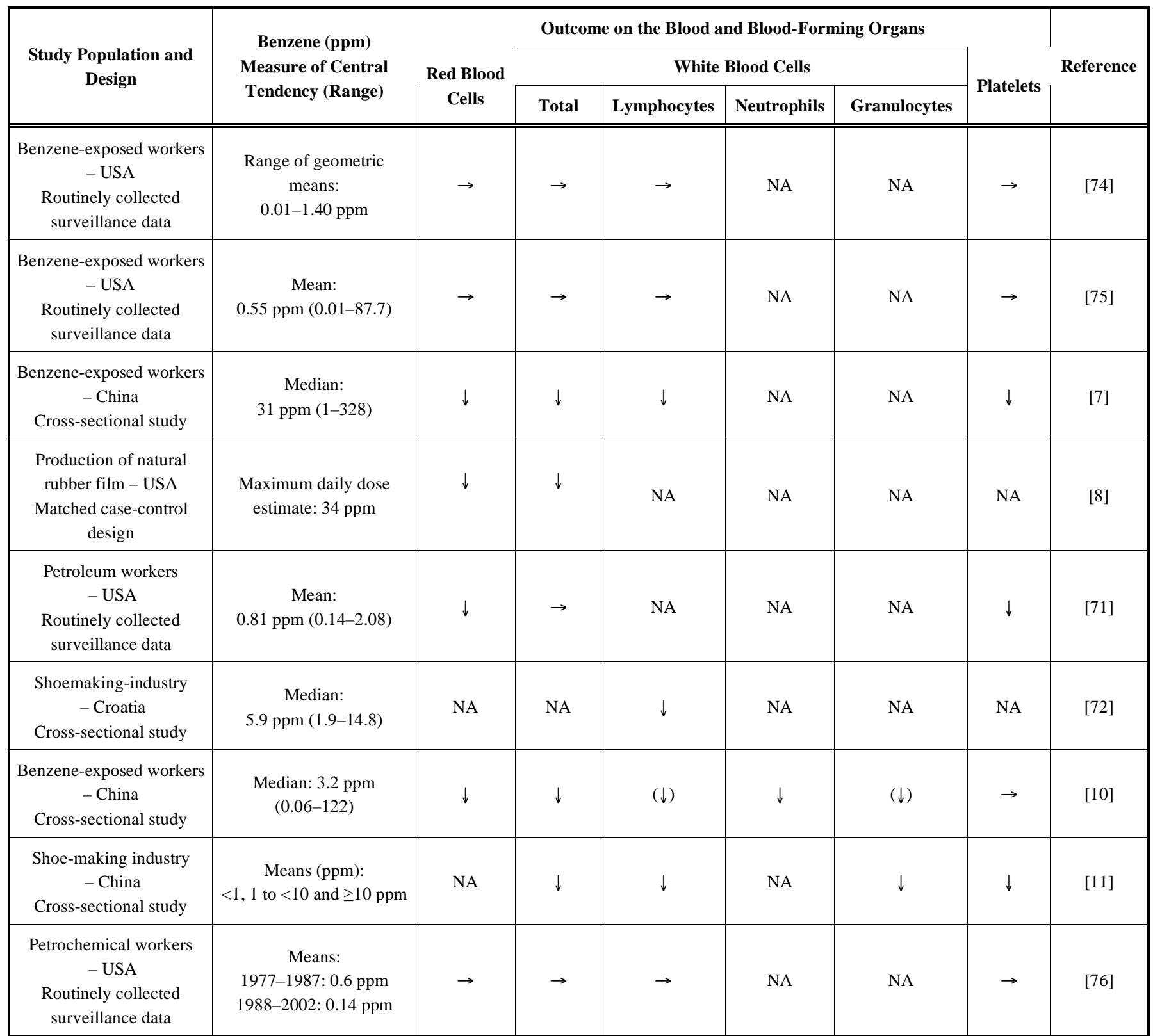

$\rightarrow:$ no difference between exposed workers and reference group. $\downarrow$ : significantly reduced level in exposed workers compared with reference group. $\uparrow:$ significantly increased level in exposed workers compared with reference group. NA: the parameter was not assessed or reported.

tion. Thus, these observations are probably not representative for western industry, where the time-weighted average exposure is generally much lower and the high exposure during specific tasks usually lasts for brief periods of the work shift $[21,24,26]$.

Table 2 summarizes the characteristics of benzeneassociated myelodysplastic syndrome from workers in China with long-term exposure [88]. A striking feature is the bone marrow hypocellularity observed in 17 of the 23 patients. For many cases, there was a lack of concordance between the severity of the marrow abnormalities and peripheral blood cytopenia. Another striking characteristic was the high frequency of normal cytogenetics, differing from chemotherapy-induced myelodysplastic syndrome that is characterized by certain chromosomal deletions (alkylating agents) or translocations (topoisomerase inhibitors) [91]. Finally, the presence of immune system abnormalities is not surprising. Myelodysplastic syndrome is associated with immune system abnormalities, reflected in the polyclonal hypergammaglobulins detected in about one third of patients [92]. A minority of myelodysplastic syndrome patients also develop autoimmune disease [92,93].

\subsection{Genetic and Epigenetic Effects in Benzene-Exposed Individuals}

\subsubsection{Chromosomal Abnormalities in Benzene-Exposed Individuals}

Monosomy of chromosome 7 , trisomy 8 and translocations between chromosomes 8 and $21(\mathrm{t}(8 ; 21))$ are chromosomal changes observed in AML $[94,95]$. An increased inci- 
Table 2. Clinical and Biological Characteristics of Myelodysplastic Syndrome Developing After Long-Term Exposure to High Benzene Concentrations; A Summary of Reported Observations for 23 Chinese Workers Previously Exposed to Benzene [88]

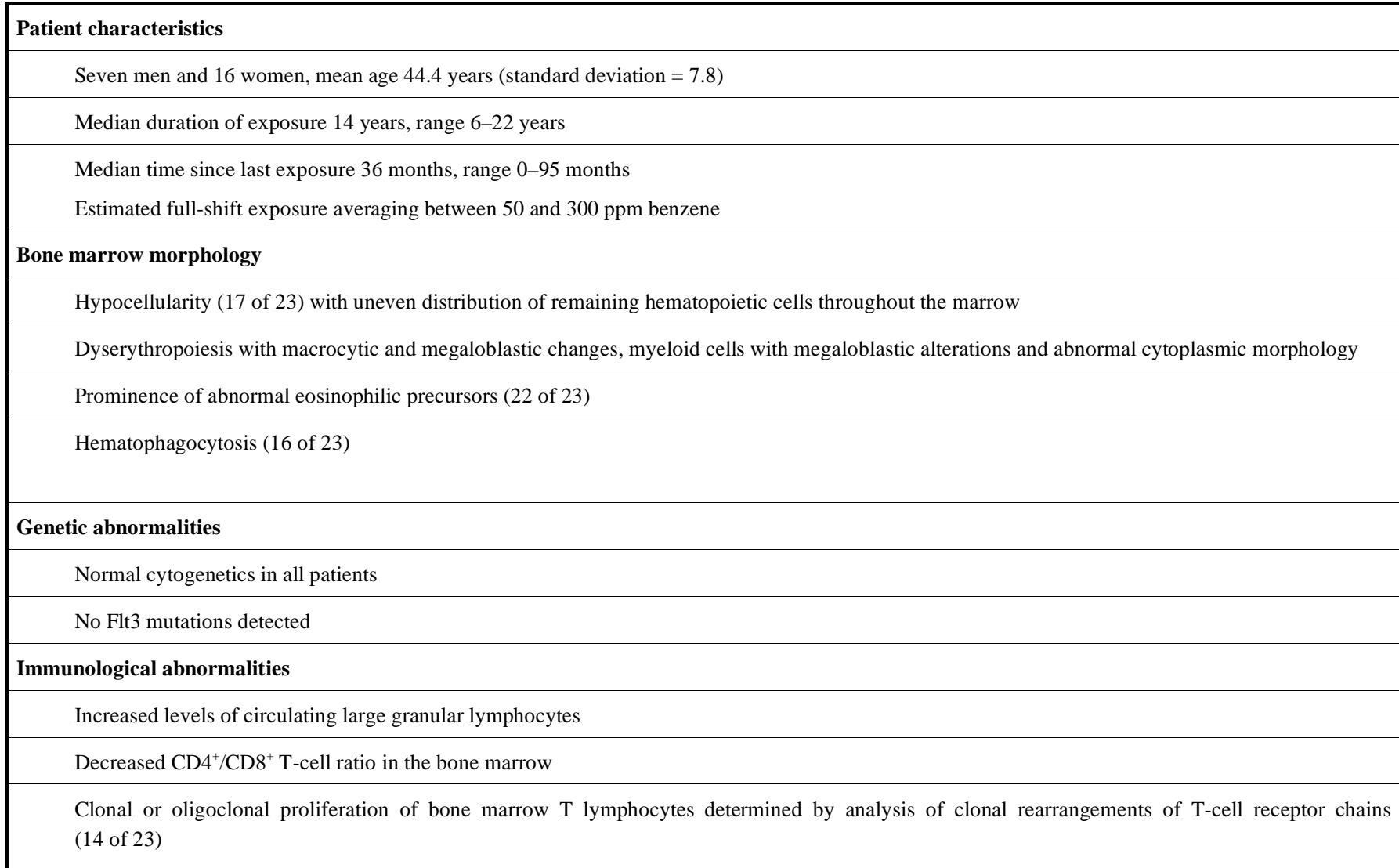

dence of these aberrations has been reported in workers exposed to benzene [96]. Studies of chromosomal abnormalities in blood cells have suggested that benzene metabolites particularly produce monosomy of chromosomes 5 and 7 in human lymphocytes from healthy workers exposed to benzene [97] and in human bone marrow cells obtained from healthy volunteers $[98,99]$, with bone marrow cells being more susceptible than lymphocytes. The aberrations $\mathrm{t}(8 ; 21)$ and trisomy 8 have also been reported [100]. In a recent pilot study comparing six benzene-exposed workers with five unexposed referents, Zhang et al. [101] reported that benzene exposure was associated with monosomy of chromosomes 5, 6, 7 and 10 and with trisomy for chromosomes 8, 9, 17,21 and 22 .

A dose-dependent induction of long-arm deletion of chromosome $6[\operatorname{del}(6 q)]$ and an increased frequency of translocation $\mathrm{t}(14 ; 18)$ among highly exposed workers have been reported [102]. Both $\mathrm{t}(14 ; 18)$ and $\operatorname{del}(6 \mathrm{q})$ are also frequently observed in lymphoma patients [103-105]. Induction of $\mathrm{t}(4 ; 11)$ and $\mathrm{t}(6 ; 11)$, common in therapy-related leukemia due to topoisomerase II-inhibiting drugs, was not found. Taken together, these observations suggest that benzene produces selective effects on certain chromosomes. Another study described an association between chromosomal abnormalities in lymphocytes and the frequency of activated $\mathrm{T}$ cells in peripheral blood among workers exposed to benzene, styrene, polycyclic aromatic hydrocarbons and/or solvents and unexposed referents [106], which suggests a link between genotoxicity and immunomodulation.
An important question then is why the benzeneassociated monosomies and trisomies are not detected in the patients with benzene-associated myelodysplastic syndromes reported by Irons et al. [88] (Table 2). The present scientific literature cannot answer this question, but possible explanations are: (i) variation in exposure; (ii) certain abnormalities may predispose to the direct development of leukemia without preleukemic myelodysplasia; or (iii) cells with these abnormalities may not survive long enough to form the basis for disease development.

\subsubsection{Oxidative stress, DNA damage and changes in DNA methylation patterns}

Several studies have reported oxidative stress [107,108] and increased single-strand breaks in the DNA of circulating blood cells [108-110] among workers exposed to benzene. A study of filling station attendants exposed to benzene [107] found a significant association between benzene exposure and the urinary oxidative DNA adduct 8-hydroxydeoxyguanosine (8-OHdG), a biomarker of oxidative stress [111]. Liu et al. [112] reported that both concentrations of benzene in air and urinary $t, t$-muconic acid were significantly associated with 8-OHdG in lymphocyte DNA, together with a correlation between $8-\mathrm{OHdG}$ and micronucleus frequency. Workers exposed to gasoline, with an average benzene exposure of $0.13 \mathrm{ppm}$ over a full shift, had an increase in singlestrand breaks in DNA of leukocytes compared with unexposed controls. Urinary $8-\mathrm{OHdG}$ increased over the shift 
among exposed workers, and the increase was significantly associated with the exposure to benzene during the shift.

In another study, comet assays were carried out to evaluate DNA damage (single-strand breaks) in T and B lymphocytes and granulocytes from benzene-exposed workers [109]. Significantly higher DNA damage, measured as tail moments, was reported among exposed workers than among referents. B lymphocytes, which have the shortest life span, were more sensitive to low levels of benzene than were the $\mathrm{T}$ lymphocytes and granulocytes. Similar results have been reported for benzene-exposed workers from a range of industries with a mean benzene exposure of $0.27 \mathrm{ppm}$ (range 0.005-2.03 ppm) [110].

Bollati et al. [113] studied aberrant DNA methylation patterns in gas station attendants and traffic police officers exposed to low benzene levels. Benzene exposure was associated with a significant reduction in global methylation and gene-specific hypermethylation ( $p 15$ gene) and hypomethylation (MAGE-1 gene). Loss of imprinting was only found in exposed subjects, but no dose response was found. Similar aberrant DNA methylation patterns have been found in subjects with AML [114].

\subsection{Possible clues to the Mechanisms Behind the Effect of Benzene on Hematopoiesis}

\subsubsection{Genotoxic Effects of Benzene}

Benzene's metabolites are non-mutagenic or weak mutagens $[115,116]$. In contrast to most other carcinogens, benzene is not assumed to directly damage the DNA. The mechanisms behind the genotoxic effect of benzene's metabolites are proposed to include concerted action with the generation of active oxygen species via redox cycling, adduct formation and damage to DNA-associated proteins such as topoisomerase II and the mitotic apparatus, with consequent damage including DNA strand breakage, mitotic recombination, chromosome translocations and aneuploidy [115,116].

Topoisomerases are nuclear enzymes that play important roles in maintaining the integrity of the genome during replication, recombination and the separation of sister chromatids [117]. Experimentally, the benzene metabolite hydroquinone can be activated to a topoisomerase II inhibitor by myeloperoxidase and $\mathrm{H}_{2} \mathrm{O}_{2}$ [118]. Benzene-derived quinones also enhance DNA cleavage and inhibit DNA ligation mediated by topoisomerase II $\alpha$ [119]. However, human studies provide little evidence that inhibition of topoisomerase II plays a role in benzene's leukemogenic effects.

Benzene induces gene-duplicating mutations in exposed humans [120]. One of the most frequent mutations in AML is a duplicating mutation of the receptor tyrosine kinase Flt3 [121], but a cause-effect relationship between this mutation and benzene exposure has never been reported.

Alternative mechanisms, involving oncogene activation such as c-Myb [122] and aryl hydrocarbon receptor activation $[123,124]$, have been proposed to be involved in benzene-induced hematotoxicity. Aryl hydrocarbon receptor activation by benzene metabolites suggests biological effects of benzene at low doses. Together, these studies suggest a complex mechanism of benzene-induced malignancies, in- cluding genotoxic damage, DNA repair failures and altered oncogenic signaling.

\subsubsection{Benzene-Induced Dysfunction of Cell Cycle Regula- tion}

Through the presence of myeloperoxidase $[66,68]$, an enzyme involved in forming the active benzene metabolite hydroquinone [67], the bone marrow may be particular prone to benzene-induced toxicity. Hydroquinone affects the differentiation of myeloblasts in mice and myeloid-derived cell lines [125] and may represent a mechanism for acute and chronic toxicity. Several experimental animal and in vitro studies [126-130] have reported benzene-induced dysregulation of cell cycle regulation in hematopoietic progenitor cells, the cells reported to be most sensitive to benzene's toxic effects.

Normal function of the tumor suppressor protein p53 is essential in DNA repair, cell cycle control and cell apoptosis. Yoon et al. [126] reported that benzene suppresses the cell cycle in hematopoietic progenitor cells (colony-forming unit-granulocyte monocyte progenitor) in mice by p53mediated overexpression of $\mathrm{p} 21$, a cyclin-dependent kinase inhibitor. This resulted not simply in suppression of hematopoiesis but rather in a dynamic change of hematopoiesis during and after benzene exposure (oscillatory changes), possibly through the genetic and epigenetic effects of benzene [127]. It has also been reported that bone marrow cells in p53-deficient mice expressed significantly reduced levels of many key genes involved in the p53-regulated DNA damage response pathways ( $p 21$, gadd45, cyclin $G$, bax and bcl2) after chronic exposure to benzene [128]. In human CD34 cells treated with the benzene metabolite 1,4-benzoquinone, induction of the cyclin-dependent kinase inhibitor p21 at the mRNA level was found, while no changes in mRNA expression were observed for p53 or the DNA repair genes rad51, xpc, xpa, ku80 and apel [131].

\subsubsection{Effects of Benzene Metabolites on the Production of Chemokines and Cytokines}

Gillis et al. [132] investigated the effects of exposure to benzene metabolites on the immune system measured by the secretion of extracellular cytokines by human peripheral blood mononuclear cells exposed to benzene metabolites. Hydroquinone enhances cytokine-dependent clonal proliferation of a subpopulation of human $\mathrm{CD} 34^{+} \mathrm{BM}$ cells, which appears to be mediated via the extracellular signal-regulated kinase/activation protein-1 signaling pathway [133-136]. Hydroquinone has also been reported to synergize with tumor necrosis factor $\alpha$ to induce apoptosis in human CD34 hematopoietic progenitor cells by inhibiting nuclear factorkappa B [137], and to inhibit macrophage-mediated immune responses by modulating intracellular signaling and protective mechanisms [138].

\section{EPIDEMIOLOGICAL STUDIES OF BENZENE TOXICITY}

\subsection{Leukemia}

Epidemiological studies of leukemia provide strong evidence for a causal association between exposure to benzene and leukemia [12]. Numerous mortality and incidence studies assessing this association have been performed mainly in benzene-exposed workers from the production of natural 
rubber film [139-142], shoe-producing industry [143,144] and the petroleum industry [19,20,145-157], but other industries and occupations have also been examined [90,158-160]. Table 3 provides an overview of studies that includes estimates of the quantitative risk of benzene exposure.

The association between benzene exposure and leukemia is strongest for AML and less clear for the other subtypes $[12,13]$. Several studies on mortality rates or cancer incidence assessing the risk of leukemia in benzene-exposed cohorts have reported an increased risk of AML $[19,20,90,142,146,147]$. A recent review on benzene exposure and leukemia subtypes including nine cohorts and 13 case-control studies from several industries [13] showed a high and significant risk of AML, with a positive doseresponse relationship across study designs. A study of a cohort of offshore workers in the petroleum industry published after this review [20] showed a relative risk of 2.9 among workers assumed to have the most extensive contact with crude oil.

There is a biologically plausible basis for suggesting benzene as a causal factor for acute lymphoblastic leukemia and chronic myeloid leukemia, which also develop in the bone marrow, and some studies of benzene-exposed workers have reported such an increased risk. The assessment of the risk of these malignancies is mainly hampered by their rarity, and Schnatter et al. [13] concluded that the data for these leukemia subtypes were sparse and inconclusive. An older meta-analysis of leukemia subtypes including 19 studies of various populations of petroleum workers [148] found no excess of acute lymphoblastic leukemia and chronic myeloid leukemia. However, the power of these analyses was low, as indicated by the failure of the same meta-analyses to show a significantly increased risk for AML.

Some epidemiological studies $[152,157]$ have reported an association between benzene exposure and chronic lymphocytic leukemia. The main problem in assessing the risk of chronic lymphocytic leukemia is the different disease classifications used over time [161] and the lack of specific information on chronic lymphocytic leukemia in most studies [162]. Schnatter et al. [13] concluded that the risk of developing chronic lymphocytic leukemia was only increased in some case-control studies, but not in the cohort studies, arguing against a major effect.

\subsubsection{Temporal Variation in Risk and Reported Latency Between Exposure and the Development of Leukemia}

Several authors have discussed the temporal variation of the risk of developing leukemia after exposure to benzene. For the Pliofilm cohort [140,141], the increased risk was reported to be attributable primarily to exposure occurring during the last 10 years preceding death $[163,164]$, and the risk was highest in the first years after exposure ended [164]. Glass et al. [165] reported a similar pattern before leukemia was diagnosed in the Health Watch cohort from the Australian petroleum industry. Further, in the large cohort of benzene-exposed workers in China, the risk for the combination of AML and related myelodysplastic syndromes was highest among workers who had only recent exposure $(<10$ years prior to diagnosis) [90].

Although the time estimates reported in studies on benzene-induced malignancies of the blood and blood-forming organs represent a combination of latency and the effect of cumulative exposure and period of employment, the observations are compatible with a wide range of latency periods for AML induced by benzene. Latency periods for leukemia, representing years between first exposure and death, ranged from 2 to 51 years in the Pliofilm cohort [141]. Among offshore workers exposed to benzene during the production of crude oil, the median time between the first year of registered engagement and the diagnosis of AML was 6 years (range 5-21) [20]. The median latency time for lymphomas and leukemias combined was 9.5 years among PhD fellows at a university laboratory and 7.5 years for students attending a basic organic chemistry course where benzene was used [166]. On the other hand, several mortality studies of workers from the petroleum industry have shown an increased risk of leukemia along with increasing duration of employment, with the highest risk among workers employed for more than 20-30 years [146,147,150,157]. The information given by Costantini et al. [144] enabled the calculation of mean and median times from first exposure to death from lymphohematopoietic cancer of 28.4 and 31.5 years, respectively (range $3-49$ years).

\subsection{Multiple Myeloma}

The association between exposure to benzene and multiple myeloma is contentious $[14,15,167,168]$. The conclusion in an older meta-analysis of 22 cohort mortality studies in the petroleum industry was that these workers were not at any increased risk of developing multiple myeloma [167]. In contrast, a more recent meta-analysis including seven cohort studies focusing on benzene-exposed workers found a significant excess in the relative risk $(\mathrm{RR}=2.13)$ [168].

Most of the studies included in the negative metaanalysis [167] were performed on a cohort known to be exposed to relatively low concentrations of benzene. In addition, multiple myeloma probably has a longer latency period than AML $[20,139,140,159]$, making the causal relation between benzene and multiple myeloma more difficult to detect epidemiologically. It has therefore been claimed that asking whether benzene causes multiple myeloma is an unreasonable question in a cohort in which the benzene effect is too weak to even observe an increased risk of AML [15]. Further, a marked limitation of the studies in the petroleum industry is the likely presence of a healthy worker effect, with overall mortality and overall cancer incidence among these workers significantly lower than in the general population $[153,154,156,169]$. The healthy worker effect might mask increased risks of multiple myeloma even in studies capable of showing an increased risk of AML.

Interestingly, in the cohort described by Sathiakumar et al. [147], with an increased risk of AML ( $R R=1.6)$ among men ever employed in the oil and gas sector, unpublished results also showed a borderline significantly increased risk of multiple myeloma $(R R=2.9)$ [170]. Sailors exposed to cargo vapor from gasoline and other light petroleum products on tankers had an increased risk of multiple myeloma [171]. The recent finding of an increased risk of multiple myeloma $(\mathrm{RR}=2.49)$ among upstream petroleum workers also showing an increased risk of AML $(\mathrm{RR}=2.89)$ provides further evidence of an association between benzene exposure and the risk of multiple myeloma [20]. Several studies have 
Table 3. Overview of Studies Assessing the Risk of Leukemia and/or Acute Myeloid Leukemia in Cohorts Occupationally Exposed to Benzene that Also Include Risk Estimates for Cumulative Benzene Exposure (ppm-years). Risk Estimates Given in Bold are Statistically Significant

\begin{tabular}{|c|c|c|c|c|c|c|c|c|}
\hline Industry & Design & $n$ & Exposure Metric & Exposure & Leukemia & $\begin{array}{l}\text { Acute Mye- } \\
\text { loid Leuke- } \\
\text { mia }\end{array}$ & $\begin{array}{c}\text { Acute Nonlym- } \\
\text { phocytic Leuke- } \\
\text { mia or Acute } \\
\text { Leukemia }\end{array}$ & Ref. \\
\hline \multirow{6}{*}{$\begin{array}{l}\text { Manufacture } \\
\text { of natural } \\
\text { rubber }\end{array}$} & \multirow{2}{*}{$\begin{array}{l}\text { Cohort study (mor- } \\
\text { tality) - USA }\end{array}$} & \multirow[t]{2}{*}{1165} & All exposed & & SMR $\underline{\mathbf{3 . 4}}$ & - & - & \multirow[t]{2}{*}{ [140] } \\
\hline & & & $\begin{array}{l}\text { Cumulative } \\
\text { exposure }\end{array}$ & $\begin{array}{l}0.001-40 \text { ppm-years } \\
40-200 \text { ppm-years } \\
200-400 \text { ppm-years } \\
>400 \text { ppm-years }\end{array}$ & $\begin{array}{l}\text { SMR } 1.1 \\
\text { SMR } 3.2 \\
\text { SMR } \underline{\mathbf{1 1 . 9}} \\
\text { SMR } \underline{\mathbf{6 6 . 4}}\end{array}$ & - & - & \\
\hline & \multirow{2}{*}{$\begin{array}{l}\text { Cohort study (mor- } \\
\text { tality) - USA } \\
\text { Update of Rinsky } \\
\text { et al. } 1987\end{array}$} & \multirow[t]{2}{*}{1291} & All exposed & & SMR $\underline{2.5}$ & - & - & \multirow[t]{2}{*}{ [141] } \\
\hline & & & $\begin{array}{l}\text { Cumulative } \\
\text { exposure }\end{array}$ & $\begin{array}{l}0.001-39.99 \mathrm{ppm}- \\
\text { years } \\
40-199.99 \text { ppm-years } \\
200-399.99 \text { ppm-years } \\
>400 \text { ppm-years }\end{array}$ & $\begin{array}{l}\text { SMR } 1.5 \\
\text { SMR } 3.2 \\
\text { SMR 5.6 } \\
\text { SMR } \underline{\mathbf{2 4 . 0}}\end{array}$ & - & - & \\
\hline & \multirow{2}{*}{$\begin{array}{l}\text { Cohort study (mor- } \\
\text { tality) - USA } \\
\text { Update of Rinsky } \\
\text { et al. } 1987\end{array}$} & \multirow{2}{*}{$\begin{array}{l}\text { Not } \\
\text { given }\end{array}$} & All exposed & & - & SMR $\underline{5.0}$ & - & \multirow[t]{2}{*}{ [142] } \\
\hline & & & $\begin{array}{l}\text { Cumulative } \\
\text { exposure }\end{array}$ & $\begin{array}{l}<40 \text { ppm-years } \\
40-200 \text { ppm-years } \\
\text { 200-400 ppm-years } \\
>400 \text { ppm-years }\end{array}$ & - & $\begin{array}{l}\text { SMR } 1.2 \\
\text { SMR - } \\
\text { SMR } \underline{\mathbf{2 7 . 2}} \\
\text { SMR } \underline{\mathbf{9 8 . 4}}\end{array}$ & - & \\
\hline \multirow{2}{*}{$\begin{array}{l}\text { Variety of } \\
\text { industries and } \\
\text { occupations } \\
\text { using ben- } \\
\text { zene }\end{array}$} & \multirow{2}{*}{$\begin{array}{l}\text { Cohort study (mor- } \\
\text { tality) - China }\end{array}$} & \multirow[t]{2}{*}{74,828} & All exposed & & $\mathrm{RR} \underline{2.5}$ & - & RR $\underline{4.1}$ & \multirow[t]{2}{*}{ [90] } \\
\hline & & & $\begin{array}{l}\text { Cumulative } \\
\text { exposure }\end{array}$ & $\begin{array}{l}<40 \text { ppm-years } \\
40-99 \text { ppm-years } \\
\geq 100 \text { ppm-years }\end{array}$ & $\begin{array}{l}\text { RR } 1.9 \\
\operatorname{RR} \underline{\mathbf{3 . 1}} \\
\operatorname{RR} \underline{\mathbf{2 . 7}}\end{array}$ & - & $\begin{array}{l}\operatorname{RR} 2.7 \\
\operatorname{RR} \underline{\mathbf{6 . 0}} \\
\operatorname{RR} \underline{\mathbf{4 . 4}}\end{array}$ & \\
\hline \multirow[t]{2}{*}{$\begin{array}{l}\text { Petroleum } \\
\text { industry }\end{array}$} & \multirow[t]{2}{*}{$\begin{array}{l}\text { Nested case- } \\
\text { control study - } \\
\text { Australia }\end{array}$} & \multirow[t]{2}{*}{$\begin{array}{l}33 \text { cases } \\
\text { of leu- } \\
\text { kemia }\end{array}$} & \multirow[t]{2}{*}{$\begin{array}{l}\text { Cumulative } \\
\text { exposure }\end{array}$} & $\begin{array}{l}\leq 1 \mathrm{ppm} \text {-years } \\
>1-2 \mathrm{ppm} \text {-years } \\
>2-4 \mathrm{ppm} \text {-years } \\
>4-8 \mathrm{ppm} \text {-years } \\
>8-16 \mathrm{ppm} \text {-years } \\
>16 \mathrm{ppm} \text {-years }\end{array}$ & $\begin{array}{l}\text { OR } 1.0 \\
\text { OR } 3.9 \\
\text { OR } \underline{\mathbf{6 . 1}} \\
\text { OR } 2.4 \\
\text { OR } \underline{\mathbf{5 . 9}} \\
\text { OR } \underline{\mathbf{9 8 . 2}}\end{array}$ & - & - & \multirow[t]{2}{*}{ [19] } \\
\hline & & & & $\begin{array}{l}\leq 4 \text { ppm-years } \\
>4-8 \text { ppm-years } \\
>8 \text { ppm-years }\end{array}$ & - & - & $\begin{array}{l}1.0 \\
\text { OR } 0.5 \\
\text { OR } \underline{7.2}\end{array}$ & \\
\hline \multirow{2}{*}{$\begin{array}{l}\text { Petroleum } \\
\text { industry }\end{array}$} & \multirow{2}{*}{$\begin{array}{l}\text { Nested case- } \\
\text { control study } \\
\text { - United Kingdom }\end{array}$} & \multirow{2}{*}{$\begin{array}{l}91 \text { cases } \\
\text { of leu- } \\
\text { kemia }\end{array}$} & All exposed & & OR 1.0 & OR 1.0 & - & \multirow[t]{2}{*}{ [150] } \\
\hline & & & $\begin{array}{l}\text { Cumulative } \\
\text { exposure }\end{array}$ & $\begin{array}{l}<0.45 \text { ppm-years } \\
0.45-4.49 \text { ppm-years } \\
4.5-44.9 \text { ppm-years } \\
\geq 45 \text { ppm-years }\end{array}$ & $\begin{array}{l}\text { OR } 1.0 \\
\text { OR } 1.4 \\
\text { OR } 2.5 \\
\text { OR } 1.4\end{array}$ & $\begin{array}{l}\text { OR } 1.0 \\
\text { OR } 2.2 \\
\text { OR } 2.8 \\
\text { OR- }\end{array}$ & - & \\
\hline
\end{tabular}


Table 3. contd....

\begin{tabular}{|c|c|c|c|c|c|c|c|c|}
\hline Industry & Design & $n$ & Exposure Metric & Exposure & Leukemia & $\begin{array}{l}\text { Acute Mye- } \\
\text { loid Leuke- } \\
\text { mia }\end{array}$ & $\begin{array}{c}\text { Acute Nonlym- } \\
\text { phocytic Leuke- } \\
\text { mia or Acute } \\
\text { Leukemia }\end{array}$ & Ref. \\
\hline $\begin{array}{l}\text { Petroleum } \\
\text { industry - } \\
\text { distribution }\end{array}$ & $\begin{array}{l}\text { Nested case- } \\
\text { control study } \\
\text { - Canada }\end{array}$ & $\begin{array}{l}14 \text { cases } \\
\text { of leu- } \\
\text { kemia }\end{array}$ & $\begin{array}{l}\text { Cumulative } \\
\text { exposure }\end{array}$ & $\begin{array}{l}<0.45 \text { ppm-years } \\
>0.45-4.5 \text { ppm-years } \\
>4.5-45 \text { ppm-years } \\
>45 \text { ppm-years }\end{array}$ & $\begin{array}{l}\text { OR } 1.0 \\
\text { OR } 0.4 \\
\text { OR } 0.2 \\
\text { OR } 1.5\end{array}$ & - & - & [149] \\
\hline \multirow{2}{*}{$\begin{array}{l}\text { Chemical } \\
\text { plants }\end{array}$} & \multirow{2}{*}{$\begin{array}{l}\text { Cohort study (mor- } \\
\text { tality) - USA }\end{array}$} & \multirow[t]{2}{*}{2266} & All exposed & & SMR 1.1 & - & SMR 1.1 & \multirow[t]{2}{*}{ [160] } \\
\hline & & & $\begin{array}{l}\text { Cumulative } \\
\text { exposure }\end{array}$ & $\begin{array}{l}<28.3 \text { ppm-years } \\
28.3-79.1 \text { ppm-years } \\
>79.1 \text { ppm-years }\end{array}$ & $\begin{array}{l}\text { SMR } 0.6 \\
\text { SMR 2.0 } \\
\text { SMR } 2.2\end{array}$ & - & $\begin{array}{l}\text { SMR } 0.9 \\
\text { SMR } 1.5 \\
\text { SMR } 1.6\end{array}$ & \\
\hline $\begin{array}{l}\text { Gas and } \\
\text { electricity } \\
\text { utility }\end{array}$ & $\begin{array}{l}\text { Nested case- } \\
\text { control study } \\
\text { - France }\end{array}$ & $\begin{array}{l}72 \text { cases } \\
\text { of leu- } \\
\text { kemia }\end{array}$ & $\begin{array}{l}\text { Cumulative } \\
\text { exposure }\end{array}$ & $\begin{array}{l}0 \text { ppm-years } \\
0.1-1.0 \text { ppm-years } \\
1.1-5.4 \text { ppm-years } \\
5.5-16.7 \text { ppm-years } \\
\geq 16.8 \text { ppm-years }\end{array}$ & $\begin{array}{l}\text { OR } 1.0 \\
\text { OR } 0.7 \\
\text { OR } 1.4 \\
\text { OR } 1.9 \\
\text { OR } \underline{\mathbf{3 . 6}} \\
\end{array}$ & - & $\begin{array}{l}\text { OR } 1.0 \\
\text { OR } 0.3 \\
\text { OR } 0.3 \\
\text { OR } 1.2 \\
\text { OR } \underline{4.6} \\
\end{array}$ & [158] \\
\hline
\end{tabular}

SMR: standardized mortality ratio. RR: rate ratio. OR: odds ratio.

also reported that proximity to oil or gas fields represent an increased population risk of developing lymphohematopoietic cancers, including multiple myeloma [172,173]. On the other hand, the increased risk of multiple myeloma reported in petroleum-related cohorts might also be related to exposure to compounds in diesel or engine exhaust other than benzene [174-176].

\subsection{Lymphoma}

Lymphoma is a group of heterogeneous malignancies. The causes of lymphoma are still largely unknown, but given the potential for benzene to affect the immune system, an association between benzene exposure and non-Hodgkin's lymphoma has been suggested. In a large cohort of workers in China with 10 or more years of benzene exposure, Hayes et al. [90] reported an RR of non-Hodgkin lymphoma of 4.2 (95\% confidence interval (CI) $1.1-15.9)$ versus 0.7 (95\% CI 0.1-7.2) for workers exposed to benzene for less than 5 years. The increased risk was found only for workers with an average exposure of $\geq 25 \mathrm{ppm}$ benzene $(\mathrm{RR}=4.7)$. Several other studies have reported an increased risk of non-Hodgkin lymphoma among workers occupationally exposed to benzene [157,177-179] or to a mixture of organic solvents rather than benzene alone $[177,180,181]$.
Except for the unpublished results of a significantly increased risk of non-Hodgkin lymphoma $(R R=2.4)$ among men ever employed in the oil and gas sector [170] and in petroleum workers hired prior to 1950 (standardized mortality ratio 1.57) [157], most cohorts of petroleum workers with a potential for benzene exposure have reported negative findings on benzene-induced non-Hodgkin lymphoma. However, negative findings in cohorts of petroleum workers might be explained by exposure in this industry not being sufficiently high to induce non-Hodgkin lymphoma or the follow-up time to detect an increased risk of non-Hodgkin lymphoma being too short.

\subsection{What Level of Benzene Exposure May Induce Ma- lignancies of the Blood and Blood-Forming Organs?}

There is no clear evidence of a threshold level below which benzene does not affect human hematopoiesis, and an increasing number of studies indicate an increased risk of leukemia at levels well below 10 ppm [19,20,90]. However, a marked limitation of studies on benzene-induced malignancies of the blood and blood-forming organs is the lack of good exposure estimates. Table 3 provides an overview of studies that estimate the quantitative risk of benzene exposure. Most studies have focused on describing the average airborne benzene exposure over a full work shift cumulated 
over the duration of employment, such as ppm-years, where cumulative exposure levels of 40 and 200 ppm-years represent 40 years of 1 and 5 ppm benzene, respectively. However, some studies are also estimating the risk for other exposure metrics, such as average exposure, exposure intensity and duration of employment.

Which exposure metric best predicts risk? The exposure metric that best predicts the risk of benzene-induced malignancies of the blood and blood-forming organs is not known, and future epidemiological studies need to better describe the variability of occupational benzene exposure. Although some of the studies assessing benzene-induced leukemia in occupational cohorts also include various exposure metrics, such as duration of exposure, exposure intensity and average exposure, most studies focus on describing the average airborne benzene exposure over a full work shift cumulated over the duration of employment, such as ppm-years. However, the number of peak exposures to benzene (above 100 $\mathrm{ppm}$ ), rather than cumulative exposure, has been proposed to best predict the risk of malignancies of the blood and bloodforming organs [159]. Among petroleum workers, exposure to concentrated benzene has resulted in a higher risk of leukemia than exposure to the same amount of benzene encountered in a more dilute form such as in petrol [19].

Nonlinear metabolism. Emerging knowledge of a nonlinear dose-related production of major metabolites, favoring the production of the hematotoxic quinones at low benzene exposure, implies that previous risk assessments probably underestimated the risk at low exposure. As several researchers $[49,50,69]$ argue, the workers exposed to benzene below $1 \mathrm{ppm}$ will be subjected to the maximum possible mass of metabolites per unit of benzene exposure due to more effective metabolism at low exposure. Further, due to this saturated metabolism, high concentrations of benzene, both as a time-weighted average and as transient peak exposures, might have diminished the effect on workers' risk of developing hematotoxic effects or malignancies of the blood and blood-forming organs as compared with low benzene exposure.

Smoking-induced risk of leukemia. As cigarette smoke is a known source of benzene exposure [48], the reported increase in AML among smokers, with a relative risk ranging from 1.4 to 2.0, further supports a leukemogenic effect at low benzene exposure [182,183]. Cigarette smoke contains several carcinogenic agents in addition to benzene, and benzene's contribution to the increased risk has not been established. However, benzene in cigarettes contributes to an estimated $8-48 \%$ of smoking-induced leukemia deaths and $12-$ $58 \%$ of smoking-induced deaths from AML [184]. Although far from being conclusive, several factors argue for benzene being an important contributor to smokers' leukemia risk, such as increased concentration of benzene, hydroquinone and catechol among smokers versus nonsmokers and similarities in the chromosome abnormalities found in smokingand benzene-induced AML [183].

\section{INFLUENCE OF POLYMORPHISM IN GENES ON THE SUSCEPTIBILITY TO BENZENE-INDUCED HEMATOTOXICITY}

The concentration of benzene and its metabolites in biological media after a given level of exposure and the sensi- tivity to the toxic effects of benzene differ between individuals. The variability in the toxicokinetics is caused by biological factors such as race, sex, age and amount of adipose tissue and environmental influences such as routes of exposure, physical activity, competitive metabolic interaction, smoking, alcohol consumption and dietary habits [185]. Individual differences in the sensitivity to the toxic effects are explained partly by polymorphisms of genes important in benzene metabolism, DNA repair or regulation of hematopoiesis.

\subsection{Enzymes Involved in Metabolizing Benzene}

Genetic variation resulting in increased activity of the activation enzymes cytochrome P450 2E1, microsomal epoxide hydrolase and myeloperoxidase and/or decreased activity of detoxification enzymes glutathione- $S$-transferase and NAD (P)H:quinone oxyreductase have all individually been associated with increased susceptibility to benzene's toxic effects. Genetic variation has been associated with leukemia $[186,187]$, benzene poisoning [188,189], leukocyte toxicity [11,190], chromosomal aberrations [191] and affected metabolism [192,193].

Myeloperoxidase's ability to metabolize phenol and hydroquinone to toxic quinones is assumed to play a key role in benzene's hematotoxic effect. Mutant genotypes of myeloperoxidase have been reported to be associated with a reduced risk of acute leukemia development, explained by less myeloperoxidase activity and diminished ability to catalyze benzene [187], while the normal expressed genotype has been associated with a rise in chromosomal aberrations [191] and a greater decline in leukocyte count [11] among benzeneexposed workers. Myeloperoxidase polymorphism has also been associated with reduced risk of other types of cancer [194,195].

\subsection{Cytokines}

Studies suggest that soluble mediators are important in developing benzene-associated hematotoxicity. Lan et al. [196] investigated the frequency of single nucleotide polymorphisms (SNPs) for 20 candidate genes involving these (hematopoiesis regulatory genes: cytokines, chemokines and adhesion molecules) pathways in 250 benzene-exposed (mean $5.44 \mathrm{ppm}$ ) and 140 unexposed workers. Lan et al. described reduced peripheral blood counts of total leukocytes, granulocytes, lymphocytes, $\mathrm{CD}^{+}{ }^{+} \mathrm{T}$ cells, CD4/CD8 ratio, $\mathrm{B}$ cells, monocytes and platelets. A significant correlation between leukopenia and SNPs of the interleukins IL-1A, IL-4, IL-10, IL-12A and vascular cell adhesion molecule 1 genes was found. The authors reported that selected variants seemed to influence only granulocytes, whereas others altered cell types of both the myeloid and lymphoid lineage, suggesting effects that could extend to earlier progenitor and possibly stem cells. Another report described an association between SNPs in the tumor necrosis factor $\alpha$ promoter region and the development of myelodysplastic syndrome (benzene-induced dysplasia) in individuals exposed to high concentrations of benzene [197]. Taken together, these two reports suggest that cytokine-mediated growth regulation is involved in benzene-associated hematotoxicity. One possible mechanism could be that these soluble mediators mediate survival growth-enhancing signaling to transformed cells. 


\subsection{Genes Involved in the Repair Pathway}

A third study of the same study population described above [196] found an association between benzene-induced hematotoxic effects and a number of SNPs in seven genes important in repairing DNA double-strand breaks [198]. Among exposed workers, one SNP in BRCA2, four SNPs in WRN and one SNP in TP53 were associated with a decrease in white blood cell counts. These three gene products play an important role in multiple mechanisms including DNA damage recognition, replication, recombination, repair and cell cycle regulation, all of which are critical to maintain genomic integrity. Further, genetic polymorphism in the gene $\mathrm{X}$-ray cross-complementation group 1 , which plays an important role in both base excision repair and single-strand repair [199], was associated with a higher frequency of chromosomal aberrations and micronuclei in a group of benzene-exposed refinery workers [191].

\section{CONCLUDING REMARKS}

Although the association between benzene exposure and AML has been established, which exposure level that causes an increased risk and which exposure pattern that best predicts the risk (cumulative versus peaks) are still uncertain. No clear evidence indicates a threshold level below which benzene does not affect human hematopoiesis or peripheral blood cell levels. Emerging knowledge of nonlinear doserelated production of major metabolites, favoring the production of the hematotoxic quinones at low benzene exposure, implies a probable underestimation in previous risk assessments of the risk at low exposure.

The scientific literature also debates the association between benzene exposure and other malignancies of the blood and blood-forming organs. Although increasing evidence indicates an association between benzene exposure and multiple myeloma, evidence for other types of chronic leukemia and lymphoma is weak. There is a biologically plausible basis for suggesting benzene as a causal factor for these malignancies, and this is especially true for malignancies of the blood and blood-forming organs developing in the bone marrow, such as multiple myeloma, acute lymphoblastic leukemia and chronic myeloproliferative disorders. The bone marrow may be particular prone to benzene-induced toxicity through the presence of myeloperoxidase, an enzyme involved in forming hydroquinone, a biologically reactive benzene metabolite. These benzene metabolites are assumed to exert their effect through a concerted action of genotoxic damage, DNA repair failures and altered oncogenic signaling. Studies of benzene-exposed workers suggest that the risk of developing hematotoxicity also depends on genetic polymorphisms in benzene-activating and detoxifying enzymes, DNA repair capacity and various growth-regulatory soluble mediators. However, additional studies of the leukemogenic effects of benzene are definitely needed, including investigations of the effects on various hematopoietic progenitor cell subsets.

Together these observations suggest that, even at low exposure levels, benzene may contribute to the risk of malignancies of the blood and blood-forming organs, especially among genetically susceptible individuals. More knowledge about how benzene exposure affects the blood cells of the human system, such as affected signaling pathways or changes in gene expression, might provide hematologists with a basis for developing detection and technologies for preventing benzene-induced hematotoxicity.

Although the fraction of malignancies of the blood and blood-forming organs that can be attributed to occupational benzene exposure is probably low in the general population, it involves high risk for various groups of workers who are unwillingly subjected to the additional burden of this exposure. Exposed workers might be subjected to an unacceptable risk that can be avoided by enforcing proper preventive measures.

\section{ACKNOWLEDGEMENTS}

The Norwegian Cancer Society and EXTRA funds from the Norwegian Foundation for Health and Rehabilitation supported the work.

\section{REFERENCES}

[1] Gilliard GD, Griffin JD. The roles of Flt3 in hematopoiesis and leukemia. Blood 2002; 100: 1532-42.

[2] Deguchi K, Gilliland DG. Cooperativity between mutations in tyrosine kinases and in hematopoietic transcription factors in AML. Leukemia 2002; 16(4): 740-4

[3] Nelson DI, Concha-Barrientos M, Driscoll T, et al. The global burden of selected occupational diseases and injury risks: Methodology and summary. Am J Ind Med 2005; 48(6): 400-18.

[4] Driscoll T, Nelson DI, Steenland K, et al. The global burden of disease due to occupational carcinogens. Am J Ind Med 2005; 48(6): 419-31.

[5] Steenland K, Burnett C, Lalich N, Ward E, Hurrell J. Dying for work: the magnitude of US mortality from selected causes of death associated with occupation. Am J Ind Med 2003; 43: 461-82.

[6] Nurminen M, Karjalainen A. Epidemiologic estimate of the proportion of fatalities related to occupational factors in Finland. Scand J Work Environ Health 2001; 27(3): 161-213.

[7] Rothman N, Smith MT, Hayes RB, et al. An epidemiologic study of early biologic effects of benzene in Chinese workers. Environ Health Perspect 1996; 104(Suppl 6): 1365-70.

[8] Ward E, Hornung R, Morris J, et al. Risk of low red or white blood cell count related to estimated benzene exposure in a rubberworker cohort (1940-1975). Am J Ind Med 1996; 29: 247-57.

[9] Hayes RB, Songnian Y, Dosemeci M, Linet M. Benzene and lymphohematopoietic malignancies in humans. Am J Ind Med 2001; 40(2): 117-26.

[10] Qu Q, Shore R, Li G, et al. Hematological changes among Chinese workers with a broad range of benzene exposures. Am J Ind Med 2002; 42: 275-85.

[11] Lan Q, Zhang L, Li G, et al. Hematotoxicity in workers exposed to low levels of benzene. Science 2004; 306(5702): 1774-6.

[12] International Agency for Research on Cancer. Benzene. IARC Monographs on the evaluation of carcinogenic risks to humans. Vol 29 (Suppl 17). Lyon, France: International Agency for Research on Cancer, 1987.

[13] Schnatter AR, Rosamilia K, Wojcik NC. Review of the literature on benzene exposure and leukemia subtypes. Chem Biol Interact 2005; 153-4: 9-21.

[14] Bergsagel DE, Wong O, Bergsagel PL, et al. Benzene and multiple myeloma: appraisal of the scientific evidence. Blood 1999; 94(4): 1174-82.

[15] Goldstein BD, Shalat SL. The causal relation between benzene exposure and multiple myeloma [letter to editor]. Blood 2000; 95(4): 1512-4.

[16] Wong O, Raabe GK. Non-Hodgkin's lymphoma and exposure to benzene in a multinational cohort of more than 308,000 petroleum workers, 1937 to 1996. J Occup Env Med 2000; 42(5): 554-68.

[17] Goldstein BD, Shalat SL. Non-Hodgkin's lymphoma and exposure to benzene in petroleum workers. [letter to editor]. J Occup Environ Med 2000; 42(12): 1133-6. 
[18] Lamm SH, Grunwald HW. Benzene exposure and hematotoxicity. Science 2006; 306(5702): 1774-6.

[19] Glass DC, Gray CN, Jolley DJ, et al. Leukemia risk associated with low-level benzene exposure. Epidemiology 2003; 14: 569-77.

[20] Kirkeleit J, Riise T, Bråtveit M, Moen BE. Increased risk of acute myelogenous leukemia and multiple myeloma in a historical cohort of upstream petroleum workers offshore. Cancer Causes Control 2008; 19(1): 13-23.

[21] Capleton AC, Levy LS. An overview of occupational benzene exposures and occupational exposure limits in Europe and North America. Chem Biol Interact 2005; 153-4: 43-53.

[22] EU Directive 2004/37/EC of the European Parliament and of the Council of 29 April 2004 on the protection of workers from the risks related to exposure to carcinogens or mutagens at work. Off $\mathbf{J}$ Eur Commun L 229/23, 29.6.2004.

[23] Glass DC, Adams GG, Manuell RW, Bisby JA. Retrospective exposure assessment for benzene in the Australian petroleum industry. Ann Occup Hyg 2000; 44(4): 301-20.

[24] Kirkeleit J, Riise T, Bråtveit M, Moen BE. Benzene exposure on a crude oil production vessel. Ann Occup Hyg 2006; 50: 123-9.

[25] Steinsvåg K, Bråtveit M, Moen BE. Exposure to carcinogens for defined job categories in Norway's offshore petroleum industry, 1970 to 2005. Occup Environ Med 2007; 64(4): 250-8.

[26] Bråtveit M, Kirkeleit J, Hollund BE, Moen BE. Biological monitoring of benzene exposure for process operators during ordinary activity in the upstream petroleum industry. Ann Occup Hyg 2007; 51(5): 487-94.

[27] Verma DK, Johnson DM, McLean JD. Benzene and total hydrocarbons exposures in the upstream petroleum oil and gas industry. AIHAJ 2000; 61: 255-63.

[28] Nordlinder R, Ramnäs O. Exposure to benzene at different work places in Sweden. Ann Occup Hyg 1987; 31(3): 345-55.

[29] Verma DK, Julian JA, Bebee G, Cheng WK, Holborn K, Shaw L. Hydrocarbon exposures at petroleum bulk terminals and agencies. Am Ind Hyg Assoc J 1992; 53(10): 645-56.

[30] Verma DK, Johnson DM, Shaw ML, des Tombe K. Benzene and total hydrocarbons exposures in the downstream petroleum industries. AIHAJ 2001; 62: 176-94.

[31] Halder CA, Van Gorp GS, Hatoum NS, Warne TM. Gasoline vapor exposures. Part I. Characterization of workplace exposures. Am Ind Hyg Assoc J 1986; 47(3): 164-72.

[32] Javelaud B, Vian L, Molle R, Allain P, Allemand B, Andre B, et al. Benzene exposure in car mechanics and road tanker drivers. Int Arch Occup Environ Health 1998; 71(4): 277-83.

[33] McDermott HJ, Vos GA. Service station attendants' exposure to benzene and gasoline vapors. Am Ind Hyg Assoc J 1979; 40(4): 315-21.

[34] Lagorio S, Forastiere F, Iavarone I, Vanacore N, Fuselli S, Carere A. Exposure assessment in a historical cohort of filling station attendants. Int J Epidemiol 1993; 22(Suppl 2): 51-6.

[35] Kivisto H, Pekari K, Peltonen K, et al. Biological monitoring of exposure to benzene in the production of benzene and in a cokery. Sci Total Environ 1997; 199(1-2): 49-63.

[36] Runion HE. Occupational exposure to potentially hazardous agents in the petroleum industry. Occup Med 1988; 3: 431-44.

[37] Durand KTH, Lees PSJ, Kern DG. Exposure assessment and respirator selection in the cleaning of crude oil process vessels. Appl Occup Environ Hyg 1995; 10(2): 120-4.

[38] Hakkola M, Saarinen L. Exposure of tanker drivers to gasoline and some of its components. Ann Occup Hyg 1996; 40(1): 1-10.

[39] Vainiotalo S, Ruonakangas A. Tank truck driver exposure to vapors from oxygenated or reformulated gasolines during loading and unloading. Am Ind Hyg Assoc J 1999; 60: 518-25.

[40] Davenport AC, Glynn TJ, Rhambarose H. Coast Guard exposure to gasoline, MTBE, and benzene vapors during inspection of tank barges. AIHAJ 2000; 61(6): 865-72.

[41] Vainiotalo S, Kuusimaki L, Pekari K. Exposure to MTBE, TAME and aromatic hydrocarbons during gasoline pump maintenance, repair and inspection. J Occup Health 2006; 48(5): 347-57.

[42] Bahrami AR, Joneidi Jafari A, Ahmadi H, Mahjub H. Comparison of benzene exposure in drivers and petrol stations workers by uri- nary trans,trans-muconic acid in west of Iran. Ind Health 2007; 45(3): 396-401.

[43] Verma DK, des Tombe K. Benzene in gasoline and crude oil: occupational and environmental implications. AIHA J 2002; 63(2): 225-30.

[44] van Wijngaarden E, Stewart P. Critical literature review of determinants and levels of occupational benzene exposure for United States community-based case-control studies. Appl Occup Environ Hyg 2003; 18(9): 678-93.

[45] Wallace L. Environmental exposure to benzene: an update. Environ Health Perspect 1996; 104 (Suppl 6): 1129-36.

[46] Duarte-Davidson R, Courage C, Rushton L, Levy L. Benzene in the environment: an assessment of the potential risks to the health of the population. Occup Environ Med 2001; 58: 2-13.

[47] Johnson ES, Langård S, Lin YS. A critique of benzene exposure in the general population. Sci Total Environ 2007; 374(2-3): 183-98.

[48] Darrall KG, Figgins JA, Brown RD, Phillips GF. Determination of benzene and associated volatile compounds in mainstream cigarette smoke. Analyst 1998; 123: 1095-101.

[49] Kim S, Vermeulen R, Waidyanatha S, et al. Using urinary biomarkers to elucidate dose-related patterns of human benzene metabolism. Carcinogenesis 2006; 27(4): 772-81.

[50] Kim S, Vermeulen R, Waidyanatha S, et al. Modeling human metabolism of benzene following occupational and environmental exposures. Cancer Epidemiol Biomarkers Prev 2006; 15(11): 224652.

[51] Pekari K, Vainiotalo S, Heikkilä P, Palotie A, Luotamo M, Riihimäki V. Biological monitoring of occupational exposure to low levels of benzene. Scand J Work Environ Health 1992; 18: 317-22.

[52] DFG (Deutsche Forschungsgemeinschaft). MAK- und BAT-WerteListe. Maximale Arbeitsplatzkonzentrationen und Biologische Arbeitsstoff-toleranzwerte, Wiley-VCH, Weinheim, 2005.

[53] EU Directive 2000/69/EC of the European Parliament and of the Council of 16 November 2000 relating to limit values for benzene and carbon monoxide in ambient air. Official Journal of the European Communities L 313, 13/12/2000 p. 0012.

[54] Fondelli MC, Bavazzano P, Grechi D, et al. Benzene exposure in a sample of population residing in a district of Florence, Italy. Sci Tot Environ 2008; 392: 41-9.

[55] Nomiyama K, Nomiyama H. Respiratory retention, uptake and excretion of organic solvents in man. Int Arch Arbeitsmed 1974; 32: 75-83.

[56] Åstrand I. Uptake of solvents from the lungs. Br J Ind Med 1985; 42: 217-8.

[57] Blank IH, McAuliffe DJ. Penetration of benzene through human skin. J Invest Dermatol 1985; 85(6): 522-6.

[58] Kalnas J, Teitelbaum DT. Dermal absorption of benzene: Implications for work practices and regulations. Int J Occup Environ Health 2000; 6: 114-21.

[59] Modjtahedi BS, Maibach HI. In vivo percutaneous absorption of benzene in man: forearm and palm. Food Chem Toxicol 2008; 46: $1171-4$.

[60] Franz, TJ. Percutaneous absorption of benzene. In: MacFarland HN, Holdsworth CE, MacGregor JA, et al. Eds. Advances in Modern Environmental Toxicology. Vol VI. Applied Toxicology of Petroleum Hydrocarbons. Princeton, NJ, Princeton Scientific Publishers. 1984: 61-70.

[61] Kezic S, Monster AC, Krüse J, Verberk MM. Skin absorption of some vaporius solvents in volunteers. Int Arch Occup Environ Health 2000; 73: 415-22.

[62] Vermeulen R, Lan Q, Li G, et al. Assessment of dermal exposure to benzene and toluene in shoe manufacturing by activated carbon cloth patches. J Environ Monit 2006; 8(11): 1143-8.

[63] Snyder R, Hedli CC. An overview of benzene metabolism. Eny Health Perspect 1996; 104; 1165-71.

[64] Witz G, Zhang Z, Goldstein BD. Reactive ring-opened aldehyde metabolites in benzene hematotoxicity. Environ Health Perspect 1996; 104(Suppl 6): 1195-9.

[65] Bernauer U, Vieth B, Ellrich R, Heinrich-Hirsch B, Jänig GR, Gundert-Remy U. CYP2E1 expression in bone marrow and its intra- and interspecies variability: approaches for a more reliable extrapolation from one species to another in the risk assessment of chemicals. Arch Toxicol 2000; 73(12): 618-24. 
[66] Bainton DF, Ullyot JL, Faraquhar MG. The development of neutrophilic polymorphonuclear leukocytes in human bone marrow. $\mathbf{J}$ Exp Med 1971; 134: 907-34.

[67] Subrahmanyam VV, Kolachana P, Smith MT. Hydroxylation of phenol to hydroquinone catalyzed by a human myeloperoxidasesuperoxide complex: possible implications in benzene-induced myelotoxicity. Free Radic Res Commun 1991; 15(5): 285-96.

[68] Tsuruta T, Tani K, Hoshika A, Asano S. Myeloperoxidase gene expression and regulation by myeloid cell growth factors in normal and leukemic cells. Leuk Lymphoma 1999; 32(3-4): 257-67.

[69] Rappaport SM, Waidyanatha S, Yeowell-O'Connel K, et al. Protein adducts as biomarkers of human benzene metabolism. Chem Biol Interact 2005; 153-4: 103-9.

[70] Lin Y-S, Vermeulen R, Tsai CH, et al. Albumin adducts of electrophilic benzene metabolites in benzene-exposed and control workers. Environ Health Perspect 2007; 115: 28-34.

[71] Khuder S, Youngdale M, Bisesi MS, Schaub EA. Assessment of complete blood count variations among workers exposed to low levels of benzene. J Occup Env Med 1999; 41(9): 821-6.

[72] Bogadi-Sare A, Zavalic M, Trosic I, Turk R, Kontosic I, Jelcic I. Study of some immunological parameters in workers occupationally exposed to benzene. Int Arch Occup Environ Health 2000; 73: 397-400

[73] Lan Q, Zhang L, Hakim F, et al. Lymphocyte toxicity and T cell receptor excision circles in workers exposed to benzene. Chem Biol Interact 2005; 153-4: 111-5.

[74] Collins JJ, Ireland BK, Easterday PA, Nair RS, Braun J. A study of the hematologic effects of chronic low-level exposure to benzene. J Occup Med 1991; 33(5): 619-26.

[75] Collins JJ, Conner P, Friedlander BR, Easterday PA, Nair RS, Braun J. Evaluation of lymphopenia among workers with low-level benzene exposure and the utility of routine data collection. J Occup Environ Med 1997; 39(3): 232-7.

[76] Tsai SP, Forx EE, Ransdell JD, Wendt JK, Waddell LC, Donnely RP. A hematology surveillance study of petrochemical workers exposed to benzene.Regul Toxicol Pharmacol 2004: 40(1): 67-73.

[77] Ray MR, Roychoudhury S, Mukherjee S, Lahiri T. Occupational benzene exposure from vehicular sources in India and its effect on hematology, lymphocyte subsets and platelet P-selectin expression. Toxicol Ind Health 2007; 23: 167-75.

[78] Kelsey KT, Ross D, Traver RD, Christiani DC, Zuo ZF, Spitz MR, et al. Ethnic variation in the prevalence of a common NAD $(\mathrm{P}) \mathrm{H}$ quinone oxidoreductase polymorphism and its implications for anti-cancer chemotherapy. Br J Cancer 1997; 76(7): 852-4.

[79] Nebert DW, Roe AL, Vandale SE, Bingham E, Oakley GG. 7NAD(P)H:quinone oxidoreductase (NQO1) polymorphism, exposure to benzene, and predisposition to disease: a HuGE review. Genet Med 2002; 4(2): 62-70

[80] Lange A, Smolik R, Zatonski W, Szymanska J. Serum immunoglobulin levels in workers exposed to benzene, toluene and xylene. Int Arch Arbeitsmed 1973; 31: 37-44.

[81] Moszczynsky P. The effect of cigarette smoking on the indexes of immunity and acute phase reaction in subjects with occupational exposure to organic solvents. Centr Eur J Public Health 1993; 1: 41-5.

[82] Kirkeleit J, Ulvestad E, Riise T, Bråtveit M, Moen BE. Acute suppression of serum IgM and IgA in tank workers exposed to benzene. Scand J Immunol 2006; 64: 690-8.

[83] Dimitrova ND, Kostadinova RY, Marinova SN, Popov TA, Panev TI. Specific immune responses in workers exposed to benzene. Int Immunopharmacol 2005; 5: 1554-9.

[84] Smolik R, Grzybek-Hryncewicz K, Lange A, Zatonski W. Serum complement level in workers exposed to benzene, toluene and xylene. Int Arch Arbeitsmed 1973; 31: 243-7.

[85] Vermeulen R, Lan Q, Zhang L, Gunn L, McCarthy, Woodbury RL, et al. Decreased levels of CXC-chemokines in serum of benzeneexposed workers identified by array-based proteomics. Proc Natl Acad Sci USA 2005; 102(47): 17041-6.

[86] Forrest MS, Lan Q, Hubbard AE, et al. Discovery of novel biomarkers by microarray analysis of peripheral blood mononuclear cell gene expression in benzene-exposed workers. Environ Health Perspect 2005; 113(6): 801-7.
[87] Smith MT. Overview of benzene-induced aplastic anaemia. Eur J Haematol Suppl 1996; 60: 107-10.

[88] Irons RD, Lv L, Gross SA, et al. Chronic exposure to benzene results in a unique form of dysplasia. Leuk Res 2005; 29(12): 137180 .

[89] Linet MS, Yin S-N, Travis LB, et al. Clinical features of hematopoietic malignancies and related disorders among benzeneexposed workers in China. Benzene Study Group. Environ Health Perspect 1996; 104(suppl 6): 1353-64.

[90] Hayes RB, Yin SN, Dosemeci M, et al. Benzene and the doserelated incidence of hematologic neoplasms in China. Chinese Academy of Preventive Medicine - National Cancer Institute Benzene Study Group. J Natl Cancer Inst 1997; 89(14): 1065-71

[91] Pedersen-Bjergaard J, Andersen MK, Andersen MT, Christiansen DH. Genetics of therapy-related myelodysplasia and acute myeloid leukemia. Leukemia 2008; 22(2): 240-8

[92] Mufti GJ, Figes A, Hamblin TJ, Oscier DG, Copplestone JA. Immunological abnormalities in myelodysplastic syndromes. I. Serum immunogobulins and autoantibodies. Br J Haematol 1986; 63: 1437.

[93] Hamblin TJ. Immunological abnormalities in myelodysplastic syndromes. Semin Hematol 1996; 33(2): 150-62.

[94] Rowley JD. Molecular genetics in acute leukemia. Leukemia 2000; 14: 513-7.

[95] Paulsson K, Johansson B. Trisomy 8 as the sole chromosomal aberration in acute myeloid leukemia and myelodysplastic syndromes. Pathol Biol 2007; 55(1): 37-48.

[96] Zhang L, Eastmond DA, Smith MT. The Nature of Chromosomal Aberrations Detected in Humans Exposed to Benzene. Crit Rev Toxicol 2002; 32(1): 1-42.

[97] Zhang L, Rothman N, Wang Y, et al. Increased aneusomy and long arm deletion of chromosomes 5 and 7 in the lymphocytes of Chinese workers exposed to benzene. Carcinogenesis 1998; 19(11): 1955-61.

[98] Stillman WS, Varella-Garcia M, Irons RD. The benzene metabolite, hydroquinone, selectively induces 5q31- and -7 in human CD $34^{+}$CD19- bone marrow cells. Exp Hematol 2000; 28(2): 16976.

[99] Escobar PA, Smith MT, Vasishta A, Hubbard AE, Zhang L. Leukaemia-specific chromosome damage detected by comet with fluorescence in situ hybridization (comet-FISH). Mutagenesis 2007; 22(5): 321-7.

[100] Smith MT, Zhang L, Wang Y, et al. Increased translocations and aneusomy in chromosomes 8 and 21 among workers exposed to benzene. Cancer Res 1998; 58(10): 2176-81.

[101] Zhang L, Lan Q, Guo W, Li G, et al. Use of OctoChrome fluorescence in situ hybridization to detect specific aneuploiy among all 24 chromosomes in benzene-exposed workers. Chem Biol Interact 2005; 153-4: 117-22.

[102] Zhang L, Rothman N, Li G, et al. Aberrations in chromosomes associated with lymphoma and therapy-related leukemia in benzene-exposed workers. Environ Mol Mutagen 2007; 48(6): 467-74.

[103] Glassman AB, Hopwood V, Hayes KJ. Cytogenetics as an aid in the diagnosis of lymphomas. Ann Clin Lab Sci 2000; 30(1): 72-4

[104] Campbell LJ. Cytogenetics of lymphomas. Pathology 2005; 37(6): 493-507.

[105] Taborelli M, Tibiletti MG, Martin V, Pozzi B, Bertoni F, Capella C. Chromosome band $6 \mathrm{q}$ deletion pattern in malignant lymphomas. Cancer Genet Cytogenet 2006; 165(2): 106-13.

[106] Biro A, Pallinger E, Major J, et al. Lymphocyte phenotype analysis and chromosome aberration frequency of workers occupationally exposed to styrene, benzene, polycyclic aromatic hydrocarbons or mixed solvents. Immunol Lett 2002; 81: 133-40.

[107] Lagorio S, Tagesson C, Forastiere F, Iavarone I, Axelson O, Carere A. Exposure to benzene and urinary concentrations of 8hydroxydeoxyguanosine, a biological marker of oxidative damage to DNA. Occup Environ Med 1994; 51(11): 739-43.

[108] Nilsson R, Nordlinder R, Høgstedt B, Karlsson A, Jarvholm B. Genotoxic effects in workers exposed to low levels of benzene from gasoline. Am J Ind Med 1996; 30(3): 317-24. 
[109] Sul D, Lee D, Im H, Oh E, Kim J, Lee E. Single strand DNA breaks in T- and B-lymphocytes and granulocytes in workers exposed to benzene. Toxicol Lett 2002; 134: 87-95.

[110] Sul D, Lee E, Lee MY, et al. DNA-damage in lymphocytes of benzene exposed workers correlates with trans,trans-muconic acids and breath benzene levels. Mutat Res 2005; 582(1-2): 61-70.

[111] Pilger A, Rüdiger HW. 8-Hydroxy-2'-deoxyguanosine as a marker of oxidative DNA damage related to occupational and environmental exposures. Int Arch Occup Environ Health 2006; 80(1): 115.

[112] Liu L, Zhang O, Feng J, Deng L, Zeng N, Yang A, Zhang W. The study of DNA oxidative damage in benzene-exposed workers. Mutat Res 1996; 370(3-4): 145-50.

[113] Bollati V, Baccareli A, Hou L, et al. Changes in DNA methylation patterns in subjects exposed to low-dose benzene. Cancer Res 2007; 67(3): 876-80.

[114] Baylin SB, Herman JG. DNA hypermethylation in tumorigenesis: epigenetics joins genetics. Trends Genet 2000; 16(4): 168-74.

[115] Smith MT. The mechanism of benzene-induced leukemia: a hypothesis and speculations on the causes of leukemia. Environ Health Perspect 1996; 104 (Suppl 6): 1219-25.

[116] Whysner J, Reddy MV, Ross PM, Mohan M, Lax EA. Genotoxicity of benzene and its metabolites. Mutat Res 2004; 566(2): 99-130.

[117] Wang JC. Cellular roles of DNA topoisomerases: a molecular perspective. Nat Rev Mol Cell Biol 2002; 3(6): 430-40.

[118] Eastmond DA, Mondrala ST, Hasegawa L. Topoisomerase II inhibition by myeloperoxidase-activated hydroquinone: a potential mechanism underlying the genotoxic and carcinogenic effects of benzene. Chem Biol Interact 2005; 153-4: 207-16.

[119] Lindsey RH, Bender RP, Osheroff N. Effects of benzene metabolites on DNA cleavage mediated by human topoisomerase II $\alpha$ : 1,4hydroquinone is a Topoisomerase II posin. Chem Res Toxicol 2005; 18: 761-70.

[120] Rothman N, Haas R, Hayes RB, et al. Benzene induces geneduplicating but not gene-inactivating mutations at the glycophorin A locus in exposed humans. Proc Natl Acad Sci USA 1995; 92(9): 4069-73.

[121] Small D. FLT3 mutations: biology and treatment. Hematology Am Soc Hematol Educ Program 2006; 1: 178-84.

[122] Wan J, Badham HJ, Winn L. The role of c-MYB in benzeneinitiated toxicity. Chem Biol Interact. 2005; 153-4: 171-8.

[123] Yoon BI, Hirabayashi Y, Kawasaki Y, et al. Aryl hydrocarbon receptor mediates benzene-induced hematotoxicity. Toxicol Sci 2002; 70(1): 150-6.

[124] Badham HJ, Winn LM. Investigating the role of the aryl hydrocarbon receptor in benzene-initiated toxicity in vitro. Toxicology 2007; 229(3): 177-85.

[125] Hazel BA, O'Connor A, Niculescu R, Kalf GF. Benzene and its metabolite, hydroquinone, induce granulocytic differentiation in myeloblasts by interacting with cellular signaling pathways activated by granulocyte colony-stimulating factor. Stem Cells 1995; 13(3): 295-310.

[126] Yoon BI, Hirabayashi Y, Kawasaki Y, et al. Mechanism of action of benzene toxicity: cell cycle suppression in hemopoietic progenitor cells (CFU-GM). Exp Hematol 2001; 29(3): 278-85.

[127] Boley SE, Wong VA, French JE, Recio L. p53 heterozygosity alters the mRNA expression of p53 target genes in the bone marrow in response to inhaled benzene. Toxicol Sci 2002; 66(2): 20915.

[128] Yoon BI, Li GX, Kitada K, et al. Mechanisms of benzene-induced hematotoxicity and leukemogenicity: cDNA microarray analyses using mouse bone marrow tissue. Environ Health Perspect 2003; 111(11): 1411-20.

[129] Hirabayashi Y, Yoon BI, Li GX, Kanno J, Inoue T. Mechanism of benzene-induced hematotoxicity and leukemogenicity: current review with implication of microarray analyses. Toxicol Pathol 2004; 32(Suppl 2): 12-6.

[130] Hirabayashi Y. p53-dependent gene profiling for reactive oxygen species after benzene inhalation: special reference to genes associated with cell cycle regulation. Chem Biol Interact 2005; 153-4: 165-70.
[131] Abernethy DJ, Kleymenova EV, Rose J, Recio L, Faiola B. Human CD34+ hematopoietic progenitor cells are sensitive targets for toxicity induced by 1,4-benzoquinone. Toxicol Sci 2004; 79(1): 82-9.

[132] Gillis B, Gavin IM, Arbieva Z, King ST, Jayaraman S, Prabhakar BS. Identification of human cell responses to benzene and benzene metabolites. Genomics 2007; 90(3): 324-33.

[133] Irons RD, Stillman WS, Colagiovanni DB, Henry VA. Synergistic action of the benzene metabolite hydroquinone on myelopathic stimulating activity of granulocyte/ macrophage colony stimulating factor in vitro. Proc Natl Acad Sci USA 1992; 89: 3691-5.

[134] Irons RD, Stillman WS. Cell proliferation and differentiation in chemical leukemogenesis. Stem Cells 1993; 11(3): 235-42.

[135] Irons RD, Stillman WS. Impact of benzene metabolites on differentiation of bone marrow progenitor cells. Environ Health Perspect 1996; 104(Suppl 6): 1247-50.

[136] Zheng JH, Pyatt DW, Gross SA, Le AT, Kerzic PJ, Irons RD. Hydroquinone modulates the GM-CSF signaling pathway in TF-1 cells. Leukemia 2004; 18(7): 1296-304.

[137] Kerzic PJ, Pyatt DW, Zheng JH, Gross SA, Le A, Irons RD. Inhibition of NF-kappaB by hydroquinone sensitizes human bone marrow progenitor cells to TNF-alpha-induced apoptosis. Toxicology 2003; 187(2-3): 127-37.

[138] Lee JY, Kim JY, Lee YG, et al. Hydroquinone, a reactive metabolite of benzene, reduces macrophage-mediated immune responses. Mol Cells 2007; 23(2): 198-206.

[139] Infante PF, Rinsky RA, Wagoner JK, Young RJ. Leukaemia in benzene workers. Lancet 1977; 2(8028): 76-8.

[140] Rinsky RA, Smith AB, Hornung R, et al. Benzene and leukemia. An epidemiologic risk assessment. N Engl J Med 1987; 316(17): 1044-50.

[141] Rinsky RA, Hornung RW, Silver SR, Tseng CY. Benzene exposure and hematopoietic mortality: a long-term epidemiologic risk assessment. Am J Ind Med 2002; 42(6): 474-80.

[142] Wong O. Risk of acute myeloid leukaemia and multiple myeloma in workers exposed to benzene. Occup Environ Med 1995; 52(6): 380-4.

[143] Aksoy M, Erdem S, Dincol. Leukemia in shoe-workers exposed chronically to benzene. Blood 1974; 44(6): 837-41.

[144] Costantini AS, Quinn M, Consonni D, Zappa M. Exposure to benzene and risk of leukemia among shoe factory workers. Scand J Work Environ Health 2003; 29(1): 51-9.

[145] Divine BJ, Barron V. Texaco mortality study: III. A cohort study of producing and pipeline workers. Am J Ind Med 1987; 11(2): 189202.

[146] Divine BJ, Hartman CM. Update of a study of crude oil production workers 1946-94. Occup Environ Med 2000; 57(6): 411-7.

[147] Sathiakumar N, Delzell E, Cole P, Brill I, Frisch J, Spivey G. A case-control study of leukemia among petroleum workers. J Occup Environ Med 1995; 37(11): 1269-77.

[148] Raabe GK, Wong O. Leukemia mortality by cell type in petroleum workers with potential exposure to benzene. Environ Health Perspect 1996; 104(Suppl 6): 1381-92.

[149] Schnatter AR, Armstrong TW, Nicolich MJ, et al. Lymphohaematopoietic malignancies and quantitative estimates of exposure to benzene in Canadian petroleum distribution workers. Occup Environ Med 1996; 53(11): 773-81.

[150] Rushton L, Romaniuk H. A case-control study to investigate the risk of leukaemia associated with exposure to benzene in petroleum marketing and distribution workers in the United Kingdom. Occup Environ Med 1997; 54(3): 152-66.

[151] Lewis RJ, Schnatter AR, Katz AM, et al. Updated mortality among diverse operating segments of a petroleum company. Occup Environ Med 2000; 57(9): 595-604.

[152] Lewis RJ, Gamble JF, Jorgensen G. Mortality among three refinery/petrochemical plant cohorts. I. 1970 to 1982 active/terminated workers. J Occup Environ Med 2000; 42(7): 721-9.

[153] Sorahan T, Nichols L, Harrington JM. Mortality of United Kingdom oil refinery and petroleum distribution workers, 1951-1998. Occup Med 2002; 52(6): 333-9.

[154] Sorahan T. Mortality of UK oil refinery and petroleum distribution workers, 1951-2003. Occup Med 2007; 57(3): 177-85. 
[155] Gun RT, Pratt NL, Griffith EC, Adams GG, Bisby JA, Robinson KL. Update of a prospective study of mortality and cancer incidence in the Australian petroleum industry. Occup Environ Med 2004; 61(2): 150-6.

[156] Gun RT, Pratt N, Ryan P, Roder D. Update of mortality and cancer incidence in the Australian petroleum industry cohort. Occup Environ Med 2006; 63: 476-481.

[157] Huebner WW, Wojcik NC, Rosamilia K, Jorgensen G, Milano CA. Mortality updates (1970-1997) of two refinery/petrochemical plant cohorts at Baton Rouge, Louisiana, and Baytown, Texas. J Occup Environ Med 2004; 46(12): 1229-45.

[158] Guenel P, Imbernon E, Chevalier A, Crinquand-Calastreng A, Goldberg M. Leukemia in relation to occupational exposures to benzene and other agents: a case-control study nested in a cohort of gas and electric utility workers. Am J Ind Med 2002; 42(2): 87-97.

[159] Collins JJ, Ireland B, Buckley CF, Shepperly D. Lymphohaematopoeitic cancer mortality among workers with benzene exposure. Occup Environ Med 2003; 60(9): 676-9.

[160] Bloemen LJ, Youk A, Bradley TD, Bodner KM, Marsh G. Lymphohaematopoietic cancer risk among chemical workers exposed to benzene. Occup Environ Med 2004; 61(3): 270-4.

[161] Linet MS, Schubauer-Berigan MK, Weisenburger DD, et al. Chronic lymphocytic leukaemia: an overview of aetiology in light of recent developments in classification and pathogenesis. $\mathrm{Br} \mathrm{J}$ Haematol 2007; 139(5): 672-86.

[162] Blair A, Purdue MP, Weisenburger DD, Baris D. Chemical exposures and risk of chronic lymphocytic leukaemia. Br J Haematol 2007; 139(5): 753-61

[163] Finkelstein MM. Leukemia after exposure to benzene: temporal trends and implications for standards. Am J Ind Med 2000; 38(1): $1-7$.

[164] Silver SR, Rinsky RA, Cooper SP, Hornung RW, Lai D. Effect of follow-up time on risk estimates: a longitudinal examination of the relative risks of leukemia and multiple myeloma in a rubber hydrochloride cohort. Am J Ind Med 2002; 42: 481-89.

[165] Glass DC, Sim MR, Fritschi L, Gray CN, Jolley DJ, Gibbons C. Leukemia risk and relevant benzene exposure period - re: followup time on risk estimates. Am J Ind Med 42:481-489, 2002. Am J Ind Med 2004; 45: 222-3.

[166] Kristensen P, Hilt B, Svendsen K, Grimsrud TK. Incidence of lymphohaematopoietic cancer at a university laboratory: a cluster investigation. Eur J Epidemiol 2008; 23(1): 11-5.

[167] Wong O, Raabe GK. Multiple myeloma and benzene exposure in a multinational cohort of more than 250,000 petroleum workers Regul Toxicol 1997; 26: 188-99.

[168] Infante PF. Benzene exposure and multiple myeloma: a detailed meta-analysis of benzene cohort studies. Ann N Y Acad Sci 2006; 1076: 90-109.

[169] Wong O, Raabe GK. A critical review of cancer epidemiology in the petroleum industry, with a meta-analysis of a combined database of more than 350,000 workers. Regul Toxicol Pharmacol 2000; 32(1): 78-98.

[170] Delzell E, Sathiakumar N, Cole P, Brill I. A case-control study of leukemia, non-Hodgkin's lymphoma and multiple myeloma among employees of Union Oil Company of California. Report submitted to Union Oil Company of California. September, 8, 1992. Section 8(e) of Toxic Substances Control Act. Available at: http://www.epa.gov/opptintr/tsca8e/pubs/8ehq/2005/october05/8eh q-0905-16223a.pdf. Accessed February 2008.

[171] Nilsson RI, Nordlinder R, Hörte L-G, Järvholm B. Leukaemia, lymphoma, and multiple myeloma in seamen on tankers. Occup Environ Med 1998; 55: 517-21.

[172] Speer SA, Semenza JC, Kurosaki T, Anton-Culver H. Risk factors for acute myeloid leukemia and multiple myeloma: a combination of GIS and case-control studies. J Environ Health 2002; 64: 9-16.

[173] Gazdek D, Strnad M, Mustajbegovic J, Nemet-Lojan Z. Lymohohematopoietic malignancies and oil exploitation in KoprivnicaKrizevci county, Croatia. Int J Occup Environ Health 2007; 13: 258-67.

[174] Sonoda T, Nagata Y, Mori M, Ishida T, Imai K. Meta-analysis of multiple myeloma and benzene exposure. J Epidemiol 2001; 11(6): 249-54.
[175] Lee WJ, Baris D, Järvholm B, Silverman DT, Bergdahl IA, Blair A. Multiple myeloma and diesel and other occupational exposures in swedish construction workers. Int J Cancer 2003; 107(1): 134-8.

[176] Sjøgren B. Pristane in Diesel Exhaust a Possible Link to Multiple Myeloma. Int J Cancer 2005; 114(3): 501.

[177] Mehlman MA. Causal relationship between Non-Hodgkin's lymphoma and exposure to benzene and benzene-containing solvents. Ann N Y Acad Sci 2006; 1076: 120-8.

[178] Smith MT, Jones RM, Smith AH. Benzene exposure and risk of Non-Hodgkin lymphoma. Cancer Epidemiol Biomarkers Prev 2007; 16(3): 385-91.

[179] Vineis P, Miligi L, Costantini AS. Exposure to solvents and risk of non-Hodgkin lymphoma: clues on putative mechanisms. Cancer Epidemiol Biomarkers Prev 2007; 16(3): 381-4.

[180] Fritschi L, Benke G, Hughes AM, Kricker A, Vajdic CM, Grulich A, et al. Risk of non-Hodgkin lymphoma associated with occupational exposure to solvents, metals, organic dusts and PCBs (Australia). Cancer Causes Control 2005; 16(5): 599-607.

[181] Miligi L, Costantini AS, Benvenuti A, et al. Occupational exposure to solvents and the risk of lymphomas. Epidemiology 2006; 17(5): 552-61

[182] International Agency for Research on Cancer. Tobacco Smoke and involuntarly smoking. IARC Monographs on the evaluation of carcinogenic risks to humans. Vol 83. Lyon, France: International Agency for Research on Cancer, 2002.

[183] Lichtman MA. Cigarette smoking, cytogenetic abnormalities, and acute myelogenous leukemia. Leukemia 2007; 21(6): 1137-40.

[184] Korte JE, Hertz-Picciotto I, Schulz MR, Ball LM, Duell EJ. The contribution of benzene to smoking-induced leukemia. Environ Health Perspect 2000; 108(4): 333-9.

[185] Löf A, Johanson G. Toxicokinetics of organic solvents: a review of modifying factors. Crit Rev Toxicol 1998; 28: 571-650.

[186] Smith MT, Wang Y, Kane E, et al. Low NAD(P)H:quinone oxidoreductase 1 activity is associated with increased risk of acute leukemia in adults. Blood 2001; 97(5): 1422-6.

[187] Zhang J, Zhu FY, Pu YP, et al. Analysis of multiple single nucleotide polymorphisms (SNPs) of myeloperoxidase (MPO) to screen for genetic markers associated with acute leukemia in Chinese Han population. J Toxicol Environ Health A 2007; 70(11): 901-7.

[188] Rothman N, Smith MT, Hayes RB, et al. Benzene poisoning, a risk factor for hematological malignancy, is associated with $\mathrm{NQ} 01609 \mathrm{C} \rightarrow \mathrm{T}$ mutation and rapid fractional excretion of chlorzoxazone. Cancer Res 1997; 57: 2839-42.

[189] Wan J, Shi J, Hui L, et al. Association of genetic polymorphisms in CYP2E1, MPO, NQO1, GSTM1, and GSTT1 genes with benzene poisoning. Environ Health Perspect 2002; 110(12): 1213-8.

[190] Wan JX, Zhang ZB, Guan JR, et al. Genetic polymorphism of toxicant-metabolizing enzymes and prognosis of Chinese workers with chronic benzene poisoning. Ann N Y Acad Sci 2006; 1076: 129-36.

[191] Kim YJ, Choi JY, Paek D, Chung HW. Association of the NQO1, $\mathrm{MPO}$, and XRCC1 polymorphisms and chromosome damage among workers at a petroleum refinery. J Toxicol Environ Health A 2008; 71(5): 333-41.

[192] Qu Q, Shore R, Li G, et al. Biomarkers of benzene: urinary metabolites in relation to individual genotype and personal exposure. Chem-Biol Interact 2005; 153-4: 85-95.

[193] Kim S, Lan Q, Waidyanatha S, et al. Genetic polymorphisms and benzene metabolism in humans exposed to a wide range of air concentrations. Pharmacogenet Genomics 2007; 17(10): 789-801.

[194] Feyler A, Voho A, Bouchardy C, Kuokkanen K, Daver P, Hirvonen A, Benhamou S. Point: myeloperoxidase -463G --> a polymorphism and lung cancer risk. Cancer Epidemiol Biomarkers Prev 2002; 11(12): 1550-4.

[195] van Schooten FJ, Boots AW, Knaapen AM, et al. Myeloperoxidase $(\mathrm{MPO})-463 \mathrm{G} \rightarrow \mathrm{A}$ reduces MPO activity and DNA adduct levels in bronchoalveolar lavages of smokers. Cancer Epidemiol Biomark Prev 2004; 13(5): 828-33.

[196] Lan Q, Zhang L, Shen M, et al. Polymorphisms in cytokine and cellular adhesion molecule genes and susceptibility to hematotoxicity among workers exposed to benzene. Cancer Res 2005; 65(20): 9574-81. 
[197] Lv L, Kerzic P, Lin G, et al. The TNF-alpha 238A polymorphism is associated with susceptibility to persistent bone marrow dysplasia following chronic exposure to benzene. Leuk Res 2007; 31(11): 1479-85

[198] Shen M, Lan Q, Zhang L, et al. Polymorphisms in genes involved in DNA double-strand break repair pathway and susceptibility to benzene-induced hematotoxicity. Carcinogenesis 2006; 27(10): 2083-9.

[199] Thompson LH, West MG. XRCC1 keeps DNA from getting stranded. Mutat Res 2000; 459(1): 1-18.

(C) Kirkeleit et al.; Licensee Bentham Open.

This is an open access article distributed under the terms of the Creative Commons Attribution License (http://creativecommons.org/licenses/by/2.5/), which permits unrestrictive use, distribution, and reproduction in any medium, provided the original work is properly cited. 